\title{
INDIGENOUS KNOWLEDGE AND CULTURE IN AUSTRALIA - THE CASE FOR SUI GENERIS LEGISLATION
}

\author{
NATALIE STOIANOFF* AND ALPANA ROY**
}

\begin{abstract}
This article makes the case for the implementation of sui generis legislation in Australia for the protection of Indigenous knowledge and culture. The article commences with a review of Australia's historical engagement with the issue of protecting Indigenous knowledge and culture, and then considers Australia's international obligations within this context. The article then provides an analysis of what has been implemented across Australia in response to its international obligations. The key issues regarding the protection of Indigenous knowledge and culture are considered together with an analysis of how international developments and domestic studies and reports are addressing those issues. Based on this experience, the authors argue for a sui generis legislative regime to protect Indigenous knowledge and culture in Australia.
\end{abstract}

\section{INTRODUCTION}

Over more than four decades much time and effort has been expended on the issue of how to recognise and protect the knowledge and culture of Aboriginal and Torres Strait Islander peoples in Australia. IP Australia has recently conducted a public consultation on this very topic. ${ }^{1}$ There have been numerous other government and non-government consultations and reports, legislation suggested and abandoned, protocols developed by various organisations, legal cases, community activism, public international engagement and private commercial arrangements over

* Professor, Faculty of Law, University of Technology Sydney.

** Associate Professor, School of Law, Western Sydney University.

1 IP Australia, Indigenous Knowledge Consultation: How should Australia Protect Indigenous Knowledge? (25 May 2015) <http://www.ipaustralia.gov.au/about-us/public-consultations/ Indigenous_Knowledge_Consultation/>. IP Australia has received eight submissions to date (these are all available on IP Australia's website at the above internet address) with the most comprehensive recommendation for a sui generis regime having been submitted by the University of Technology Sydney comprising the 'White Paper' prepared for the New South Wales Office of Environment and Heritage: Natalie Stoianoff, Ann Cahill and Evana Wright, 'Recognising and Protecting Aboriginal Knowledge Associated with Natural Resource Management' (White Paper, University of Technology Sydney and North West Local Land Services, 30 September 2014) <http://www.ipaustralia.gov.au/ pdfs/UTS> ('UTS Submission'). 
several decades. ${ }^{2}$ Yet there still is no adequate legislative regime that achieves such recognition and protection in Australia.

Western intellectual property laws have developed over centuries to protect the cultural expressions, creativity and ingenuity of society. However, what is apparent from the four decades of investigation and discourse on Indigenous knowledge and culture in Australia is the inappropriateness of using Western intellectual property laws to protect the knowledge and culture of Aboriginal and Torres Strait Islander peoples living in Australia. ${ }^{3}$ The World Intellectual Property Organization ('WIPO') conducted its own analysis into the suitability of intellectual property laws to provide such protection to traditional or Indigenous knowledge and cultural expressions. ${ }^{4}$ This 'gap analysis' reinforced the importance of the work of the Intergovernmental Committee on Intellectual Property and Genetic Resources, Traditional Knowledge and Folklore ('Intergovernmental Committee') which was established in 2000 by the WIPO as a new division to cover Traditional Knowledge, Genetic Resources and Traditional Cultural Expressions/Folklore. ${ }^{5}$ The Intergovernmental Committee has been developing model sui generis or stand-alone regimes as draft treaties to protect each of the three forms of subject matter, namely, traditional knowledge; ${ }^{6}$ genetic resources; ${ }^{7}$ and traditional cultural expressions. ${ }^{8}$ Australia has played an active role in these

2 For a comprehensive overview, particularly from the perspective of cultural expressions, see Kathy Bowrey, 'International Trade in Indigenous Cultural Heritage: an Australian Perspective' in Christoph Beat Graber, Karolina Kuprecht and Jessica Christine Lai (eds), International Trade in Indigenous Cultural Heritage: Legal and Policy Issues (Edward Elgar Publishing, 2012) 396. For a useful summary see Terri Janke's submission to IP Australia's public consultation on Indigenous Knowledge: Terri Janke and Peter Dawson, 'New Tracks: Indigenous Knowledge and Cultural Expression and the Australian Intellectual Property System' Submission to IP Australia, Finding the Way: A Conversation with Aboriginal and Torres Strait Islander Peoples, 31 May 2012, 28-9<http:// www.ipaustralia.gov.au/pdfs/Submission_Terri_Janke_and_Company_IP_Lawyers.pdf $>$.

3 See Law Reform Commission of Western Australia, Aboriginal Customary Laws: The Interaction of Western Australian Law with Aboriginal Law and Culture, Final Report No 94 (2006) ('LRCWA Report').

4 WIPO Intergovernmental Committee on Intellectual Property and Genetic Resources, Traditional Knowledge and Folklore, The Protection Of Traditional Cultural Expressions: Draft Gap Analysis, 13th sess, WIPO/GRTKF/IC/13/5(b) Rev (11 October 2008) 23-4.

5 For a discussion on the gap analysis see Natalie P Stoianoff, 'Navigating the Landscape of Indigenous Knowledge - A Legal Perspective' [2012] 90 Intellectual Property Forum 23. See further Patricia Adjei and Natalie Stoianoff, 'The World Intellectual Property Organisation (WIPO) and the Intergovernmental Committee: Developments on Traditional Knowledge and Cultural Expressions' [2013] 92 Intellectual Property Forum 37, 37-8. See also Indigenous Knowledge Forum Organising Committee, Report on the Indigenous Knowledge Forum 2012 (31 October 2012) 4 <http://www. indigenousknowledgeforum.org/images/ikf-report.pdf $>$. See generally Christopher Sexton and Natalie P Stoianoff, 'Editorial — Intellectual Property Law and Indigenous Traditional Knowledge' [2013] 92 Intellectual Property Forum 4.

6 WIPO Intergovernmental Committee, The Protection of Traditional Knowledge: Draft Articles, $28^{\text {th }}$ sess, WIPO/GRTKF/IC/28/5 (2 June 2014).

7 WIPO Intergovernmental Committee, Consolidated Document Relating to Intellectual Property and Genetic Resources, $28^{\text {th }}$ sess, WIPO/GRTKF/IC/28/4 (2 June 2014).

8 WIPO Intergovernmental Committee, The Protection of Traditional Cultural Expressions: Draft Articles, $28^{\text {th }}$ sess, WIPO/GRTKF/IC/28/6 (2 June 2014). 
negotiations, ${ }^{9}$ like other member nations. ${ }^{10}$ A review of Australia's contributions illustrates an alignment with the views of the United States of America, the European Union, Japan, Canada and New Zealand favouring treaties with more general terminology and not resorting to lists of inclusions or exclusions to ensure these international instruments are not trying to create domestic law. ${ }^{11}$ In addition, Australia's contribution would seem to emphasise the need for these treaties to be aligned with matters the WIPO could address, thereby emphasising the link to intellectual property rights. ${ }^{12}$ However, this would seem to be in contradiction with the 'gap analysis' mentioned above, which recognises the need to move beyond intellectual property rights principles in order to provide appropriate protection for Indigenous knowledge and culture. ${ }^{13}$

Of course, the WIPO is not the only forum dealing with Indigenous knowledge and culture. There are several international treaties and declarations which recognise the significance of traditional and Indigenous knowledge and cultural expressions, and emphasise the need to respect, preserve and maintain knowledge, innovations and practices of Indigenous and local communities. ${ }^{14}$ The Convention on Biological Diversity ('CBD') is one example. ${ }^{15}$ This international instrument brings together the natural environment with knowledge and culture providing member nations with the opportunity to establish regimes that would regulate foreign and domestic access to valuable genetic resources and traditional and Indigenous knowledge while establishing benefit-sharing mechanisms relating to that access. The $C B D$ has also led to significant international debate on the interrelationship with intellectual property rights, particularly patent rights and plant breeders' rights, which can be developed from such genetic resources.

Intertwined with this debate has been the impact of the role of Indigenous or traditional knowledge which is not protected under conventional (usually

9 See Russell Taylor, WIPO Indigenous Panel on Free, Prior and Informed Consent: Experiences in the Fields of Genetic Resources, Traditional Knowledge and Traditional Cultural Expressions. Experiences from Australia, 16th sess, WIPO/GRTKF/IC/16/INF/5(F) (3 May 2010); WIPO Intergovernmental Committee, Policies, Measures and Experiences Regarding Intellectual Property and Genetic Resources: Submission by Australia, $16^{\text {th }}$ sess, WIPO/GRTKF/IC/16/INF/18 (19 February 2010); WIPO Intergovernmental Committee, Submission by Australia, Canada, New Zealand, Norway and the United States of America, 16th sess, WIPO/GRTKF/IC/16/7 (6 May 2010).

10 For an overview see submissions by various nations in WIPO Intergovernmental Committee, Meeting Documents, $16^{\text {th }}$ sess, WIPO/GRTKF/IC/16 (3-7 May 2010).

11 See, eg, WIPO Intergovernmental Committee, Report, $19^{\text {th }}$ sess, WIPO/GRTKF/IC/19/12 (23 February 2012) 11 [39], 22 [116-19].

12 Ibid. For example see the discussion on 'traditional creativity' versus 'traditional artistic creativity': at 11 [39].

13 This view is clearly expressed by the Indigenous Advisory Committee in their submission to IP Australia's current public consultation: Indigenous Advisory Committee, 'Indigenous Cultural and Intellectual Property', Submission to IP Australia, Indigenous Knowledge Consultation: How Should Australia Protect Indigenous Knowledge?, June 2012, $5<\mathrm{http}$ //www.ipaustralia.gov.au/about-us/ public-consultations/Indigenous_Knowledge_Consultation/>.

14 For a comprehensive list see Michael Dodson and Olivia Barr, 'Breaking the Deadlock: Developing an Indigenous Response to Protecting Indigenous Traditional Knowledge' (2007) 11(2) Australian Indigenous Law Review 19, 20-1.

15 Convention on Biological Diversity, opened for signature 5 June 1992, 1760 UNTS 79 (entered into force 29 December 1993) 
Western) intellectual property regimes. The WIPO commenced its involvement in this debate when it, together with the United Nations Environment Programme ('UNEP') responsible for the introduction of the $C B D$, jointly commissioned 'a study on the role of intellectual property rights in the sharing of benefits arising from the use of biological resources and associated traditional knowledge'. ${ }^{16}$ This fact-finding mission, where consultants, Indigenous experts, and relevant stakeholders examined the issues around the protection of Indigenous knowledge, led to the report: 'Intellectual Property Needs and Expectations of Traditional Knowledge Holders: WIPO Report on Fact-Finding Missions on Intellectual Property and Traditional Knowledge (1998-1999)' (April 2001).

Meanwhile, utilising the powers conferred under the $C B D$, many nations have already introduced sui generis or stand-alone legislation for the protection of traditional or Indigenous knowledge and/or culture, and these include: South American nations such as Brazil, ${ }^{17}$ Costa Rica ${ }^{18}$ and Peru; $;{ }^{19}$ the Philippines, ${ }^{20}$ Portugal; ${ }^{21}$ India; ${ }^{22}$ and China. ${ }^{23}$ These nations have recognised the immense value that such knowledge brings not only to their Indigenous communities but also to their nation. In so doing there are some key elements to a sui generis regime that these countries have adopted, namely: the need to identify the knowledge to be protected and the custodians of that knowledge, utilising, for instance, databases; identifying the beneficiaries; identifying the rights of the beneficiaries (Indigenous communities) over their collective knowledge; the need for free prior and informed consent of custodians of that knowledge before it can be accessed by third parties; the negotiation of benefit-sharing arrangements on mutually agreed terms; the need for a competent authority to manage the process of engagement with Indigenous/local communities and to deal with disputes among such communities as well as consequences for infringement of the rights of the Indigenous communities over their knowledge.

Australia has not taken this step, and by not taking this step is potentially placing valuable medicinal and ecological knowledge at risk of being absorbed into the public domain - without appropriate compensation provided to the traditional knowledge holders. Given the history of colonialism, dispossession, systemic racism, marginalisation, and the past (and continuing) injustice experience

16 WIPO General Assembly, Matters Concerning Intellectual Property And Genetic Resources, Traditional Knowledge and Folklore, $26^{\text {th }}$ sess, WO/GA/26/6 (25 August 2000) 2.

17 Genetic Heritage and Traditional Knowledge Provisional Act No. 2186-16 (Brazil) (entered into force 24 August 2001).

18 Biodiversity Law No 7788 (Costa Rica) (entered into force 27 May 1998).

19 Law No 27811 Introducing a Protection Regime for the Collective Knowledge of Indigenous People Derived from Biological Resources (Peru) (entered into force 11 August 2002).

20 Indigenous Peoples Rights Act of 1997 (Philippines).

21 Decree-Law No 118 of 2002 Establishing a Legal Regime of Registration, Conservation, Legal Custody and Transfer of Plant Endogenous Material (Portugal).

22 Biological Diversity Act 2002 (India); Scheduled Tribes and Other Traditional Forest Dwellers (Recognition of Forest Rights) Act 2006 (India).

23 For example, Intangible Cultural Heritage (People's Republic of China) Order No 42, 1 June 2011. In addition, there are several legislative instruments protecting and regulating traditional Chinese medicines. 
of Aboriginal and Torres Strait Islander people in Australia, appropriate compensation for this knowledge is particularly important. There are several projects underway around Australia designed to bring together Western science and Indigenous knowledge and establish publicly available databases of that knowledge. Similarly, there are various joint government activities drawing upon Indigenous knowledge for natural resource and land management that showcase the employment of Aboriginal rangers as a key outcome for Aboriginal communities. However, without an appropriate legal framework from which such well-intentioned projects can operate, the authors argue that the end result is likely to produce irreparable loss to the traditional knowledge holders and their communities.

This article commences with a review of Australia's historical engagement with the issue of protecting Indigenous knowledge and culture, and then considers Australia's international obligations within this context. The article then provides an analysis of what has been implemented across Australia in response to its international obligations. The key issues regarding the protection of Indigenous knowledge and culture are considered together with an analysis of how international developments are addressing those issues. Based on what is happening internationally the authors argue for a sui generis or stand-alone legislative regime to protect Indigenous knowledge and culture in Australia.

In order to confine the issues discussed in this paper a few provisos are necessary. First, this paper will not provide a detailed analysis of why a sui generis or standalone regime is important for different species of Australian intellectual property law (such as copyright, patents, trade marks, designs and cultural property). Rather, the purpose of this paper is to argue more broadly for the implementation of a sui generis regime drafted specifically for the protection of Australian Indigenous knowledge and culture. The authors argue that this is important given the international developments in this field, and particularly given the widely acknowledged failure of attempting to use Western intellectual property laws to protect Indigenous knowledge and culture. Secondly, this article does not discuss in detail the meaning of Indigenous knowledge and culture, or deal with the complex questions relating to Indigenous identity, as there has already been much discourse on the meaning of those terms (and related terms) and ultimately, it is for the relevant Indigenous peoples around the world to identify what they consider encapsulates their knowledge/s, culture/s, and identity/ties. ${ }^{24}$ Thirdly, the authors do not embark on a separate analysis of the shortcomings of Western intellectual property laws to protect Indigenous knowledge and culture as, again, there has been much discourse on that issue, ${ }^{25}$ and the WIPO gap analysis discussed below is adequate for the purposes of this article. Finally, the authors do not discuss in detail the meaning of the term 'sui generis' for the same reason that it has

24 For an overview of how Australia's Indigenous groups have been defined and constructed by Western discourse(s) see Bowrey, 'International Trade in Indigenous Cultural Heritage', above n 2, 396-404.

25 See generally, Alpana Roy, 'Intellectual Property Rights: A Western Tale' (2008) 16 Asia Pacific Law Review 219; Alpana Roy, 'Copyright: A Colonial Doctrine in a Postcolonial Age' (2008) 26(4) Copyright Reporter 112. 
been extensively considered elsewhere, ${ }^{26}$ but use the term to simply mean 'stand alone' or unique legislation currently outside the existing Australian intellectual property legislative regime, which has been specifically drafted for the purpose of protecting Australia's Indigenous knowledge and culture. ${ }^{27}$

\section{AN OVERVIEW OF PAST ATTEMPTS TO PROTECT INDIGENOUS KNOWLEDGE AND CULTURE IN AUSTRALIA}

This section will only detail some of the major attempts made in relation to the complex issue of how to adequately protect Australian Indigenous knowledge and culture using existing legal regimes - a question Australia has grappled with for more than forty years. ${ }^{28}$ The Commonwealth government established a working party in 1974 to examine the protection of Aboriginal folklore, and in 1981 a report was produced as a result of the working party's investigations. ${ }^{29}$ The working party's major recommendation was the enactment of an Aboriginal Folklore Act, which would protect Indigenous artistic and cultural material against improper use. However, the recommendations of the report were not acted upon, and subsequently no such Act was drafted.

In 1986, an extensive study was carried out by the Australian Law Reform Commission (ALRC) on the recognition of Aboriginal customary laws. ${ }^{30}$ The ALRC Report was based on wide-ranging consultations with Aboriginal and non-Aboriginal people, and applied a flexible (or 'functional') approach towards the recognition of Aboriginal customary law in five areas: marriage, children and family property; the criminal law and sentencing; problems of evidence and procedure; local justice mechanisms for Aboriginal communities; and hunting, fishing and gathering rights. ${ }^{31}$ The ALRC Report also supported special legislative measures for 'the use of sacred secret material other than in accordance with custom, secondly, the mutilation, destruction debasement or export of items of folklore, and thirdly, the use of items of folklore for commercial gain without payment of remuneration to traditional owners' ${ }^{32}$ The recommendations of the report with respect to intellectual property have again not been acted upon.

See, eg, John Borrows and Leonard I Rotman, 'The Sui Generis Nature of Aboriginal Rights: Does it Make a Difference?' (1997) 36 Alberta Law Review 9.

The Encyclopaedic Australian Legal Dictionary (LexisNexis Butterworths, 2011) defines the Latin term 'sui generis' as 'belonging to a species all of its own; unique'. See also Concise Australian Legal Dictionary (LexisNexis Butterworths, $5^{\text {th }}$ ed, 2015) 610.

28 For example, the application of copyright law in relation to Aboriginal art being raised in the 1966 incident concerning the new one dollar note depicting David Malangi's art during the term of Herbert (Nugget) Coombs as Governor of the Reserve Bank of Australia, and the action for breach of confidence being determined in the case of Foster v Mountford \& Rigby Ltd (1976) 14 ALR 71.

9 The working party's findings are recorded in the Department of Home Affairs and Environment, Report of the Working Party on the Protection of Aboriginal Folklore (Canberra, 4 December 1981).

Australian Law Reform Commission, Recognition of Aboriginal Customary Laws, Report No 31 (1986) ('ALRC Report').

Ibid.

Ibid [470] (citations omitted). 
The Commonwealth government in 1994 released an Issues Paper which focused on the copyright regime and the protection of Indigenous arts and cultural expression. ${ }^{33}$ An Inter-Departmental Committee on Indigenous Arts and Cultural Expression was established to evaluate submissions, consider legislative and policy reforms and make recommendations. However, the change of government in 1996 shifted the focus of reform in this area, and no report was produced by the new government in response to the numerous submissions received.

In 1997, the Aboriginal and Torres Strait Islander Commission ('ATSIC') established an Indigenous Reference Group on Indigenous Cultural and Intellectual Property ('IRG'), and also funded the Australian Institute of Aboriginal and Torres Strait Islander Studies ('AIATSIS') to develop reforms for the protection and recognition of Indigenous cultural and intellectual property. Terri Janke's influential Our Culture Our Future report recommended various reforms, including sui generis legislation to protect Indigenous cultural and intellectual property. ${ }^{34}$ However, again, the report did not actually result in any legislative reform of Australia's intellectual property laws.

While there have been several Australian cases which have considered the legal issues relating to the protection of Indigenous knowledge and culture, three copyright cases in the 1990s very clearly exposed the extent of the difficulties of using Western intellectual property laws to protect Indigenous art: Yumbulul v Reserve Bank of Australia; ${ }^{35}$ Milpurrurru v Indofurn Pty Ltd ${ }^{36}$ and Bulun Bulun $v R \& T$ Textiles Pty Ltd. ${ }^{37}$ What these cases revealed was that while Western copyright law could be used to protect the individual rights of Indigenous artists, it could not be adequately used to protect the communal interests (and rights) of Indigenous communities. ${ }^{38}$ Copyright law does not provide for a communal right over images or stories - although other legal remedies may be available (such as the recognition of a fiduciary relationship between the artist and his/her community). ${ }^{39}$ While the Copyright Amendment (Indigenous Communal Moral Rights) Bill 2003 (Cth) attempted to introduce a communal right, it received little

33 Attorney-General's Department, 'Stopping the Rip-Offs: Intellectual Property Protection for Aboriginal and Torres Strait Islander Peoples' (Issues Paper, Commonwealth of Australia, October 1994).

34 Terri Janke, AIATSIS and ATSIC, Our Culture Our Future: Report on Australian Indigenous Cultural and Intellectual Property Rights (1998) ('Our Culture Our Future').

35 (1991) 21 IPR 481.

36 (1994) 54 FCR 240.

37 (1998) 86 FCR 244.

38 For an excellent analysis of this issue see Kimberlee Weatherall, 'Culture, Autonomy and Djulibinyamurr: Individual and Community in the Construction of Rights to Traditional Designs' (2001) 64 Modern Law Review 215.

39 Bulun Bulun $v R \& T$ Textiles Pty Ltd (1998) 86 FCR 244. See also Kirby J's comments in Western Australia $v$ Ward (2002) 213 CLR 1, 247-8, where his Honour stated that intellectual property rights could be recognised as an incident of native title. Notably, Kirby J commented later in the judgment that 'it must also be accepted that the established laws of intellectual property are ill-equipped to provide full protection' of Indigenous knowledge and culture: at 248. 
exposure and did not proceed (even after a second attempt was made three years later). ${ }^{40}$

Prior to the 2003 Bill, the National Indigenous Arts Advocacy Association ('NIAAA') launched the 'Label of Authenticity' in 1999 designed to provide a national certification system for the authenticity of Indigenous art. ${ }^{41} \mathrm{~A}$ Collaboration Mark was also launched to certify works which were the result of collaboration, under fair terms, between an Aboriginal or Torres Strait Islander and a non-Indigenous manufacturer or other collaborator. ${ }^{42}$ These marks were registered under the Trade Marks Act 1995 (Cth). However the system of certification was short lived with the NIAAA being disbanded in 2002 without the marks being assigned to another certification body that could continue to control the use of the marks. ${ }^{43}$ Consequently, this national method of identifying authentic Indigenous art has given way to more local or community based methods of certification. ${ }^{44}$

The Law Reform Commission of Western Australia's report in September 2006 into the recognition of Indigenous customary laws in Australia ('LRCWA Report') exposed the inappropriateness of using Western intellectual property laws to protect the intellectual and cultural products of Indigenous people..$^{45}$ The $L R C W A$ Report, and a related background paper to the report, ${ }^{46}$ highlighted some of the fundamental differences and irreconcilable worldviews between Indigenous and non-Indigenous peoples on cultural and intellectual property. ${ }^{47}$ The $L R C W A$ Report contained a total of 131 recommendations, with three recommendations (recommendations 80, 81, and 82) focusing on the importance of recognising and protecting Indigenous cultural and intellectual property. Recommendation 80 provided for protocols relating to the protection of Indigenous cultural and intellectual property. ${ }^{48}$ Recommendation 81 was concerned with 'protocols to regulate "bioprospecting" of Indigenous knowledge'. ${ }^{49}$ Finally, recommendation 82 acknowledged the importance of 'state support for enhanced protection of

Stoianoff, 'Navigating the Landscape of Indigenous Knowledge', above n 5, 32-3. For an in-depth analysis of the Bill see Jane Anderson, 'The Politics of Indigenous Knowledge: Australia's Proposed Communal Moral Rights Bill’ (2004) 27 University of New South Wales Law Journal 585.

41 Aboriginal Education Board of Studies NSW, The Label of Authenticity and the Collaboration Mark $<$ http://ab-ed.boardofstudies.nsw.edu.au/go/aboriginal-art/protecting-australian-indigenous-art/ background-information/protection-the-issues/the-label-of-authenticity-and-the-collaborationmark>.

42 Ibid.

43 Ibid.

44 Ibid.

45 LRCWA Report, above n 3.

46 Terri Janke and Robynne Quiggin, 'Indigenous Cultural and Intellectual Property and Customary Law', (LRCWA Report, Background Paper No 12, January 2006) 451-506.

47 While it is beyond the scope of this paper to engage with the various theoretical perspectives on these fundamental differences, see for example Roy's discussion of some of these tensions within the context of postcolonial theory: Alpana Roy, 'Postcolonial Theory and Law: A Critical Introduction' (2008) 29 Adelaide Law Review 315, 351-2. See more generally Weatherall, above n 38. For an Indigenous viewpoint, see WIPO Intergovernmental Committee, Statement by the Tulalip Tribes of Washington on Folklore, Indigenous Knowledge, and the Public Domain, $5^{\text {th }}$ sess, (9 July 2003). 
Indigenous cultural and intellectual property'. ${ }^{50}$ Regrettably, there has been no further progression on recommendations 80,81 , and 82 to date. While the $L R C W A$ Report is concerned with the reform of Western Australian laws, intellectual property laws in Australia fall within the legislative power of the Commonwealth. ${ }^{51}$ For this reason, any legislative reform of Australia's intellectual property laws must be undertaken by the federal Parliament. However, the states and territories do have the power to legislate in relation to environmental laws which could provide a framework for dealing with the use of Indigenous knowledge in the context of natural resources. Indeed, this is clearly demonstrated by the UTS Submission to IP Australia's current public consultation on how to protect Indigenous Knowledge. ${ }^{52}$

In 2009 it was proposed that a National Indigenous Cultural Authority be established 'to facilitate consent and payment of royalties; to develop standards of appropriate use to guard cultural integrity, and to enforce [Indigenous cultural and intellectual property] rights'. ${ }^{53}$ There has been no further progress on such an authority in Australia although there have been various developments in this specific area overseas which are discussed in further detail below. Before considering what action has been taken in Australia in this field the following section will first detail Australia's international obligations in relation to the protection of Indigenous knowledge and culture.

\section{AUSTRALIA'S INTERNATIONAL OBLIGATIONS}

In addition to the intellectual property power mentioned above, the federal Parliament has the power to legislate on those matters relevant to its external affairs power under the Constitution. ${ }^{54}$ Regionally, the federal Parliament has the power to legislate regarding the relations of the Commonwealth with the islands of the Pacific. ${ }^{55}$ More specifically, and perhaps controversially, the federal Parliament has the power to make laws in relation to "the people of any race for whom it is deemed

50 Ibid 268.

51 Commonwealth Constitution s 51(xviii).

52 See UTS Submission, above $\mathrm{n} 1$.

53 Terri Janke, Beyond Guarding Ground: A Vision for a National Indigenous Cultural Authority (Terri Janke and Company Pty Ltd, 2009) 6.

54 Commonwealth Constitution s 51(xxix).

55 Ibid s 51(xxx). 
necessary to make special laws'. ${ }^{56}$ These powers make it quite clear that the federal Parliament has no limitation in developing special laws in relation to Indigenous knowledge and cultural expressions that would live up to the expectations of the various international instruments dealing with these issues.

These international instruments include, among others:

- $\quad$ the Universal Declaration of Human Rights, adopted by the UN General Assembly on 10 December 1948;

- the 1970 UNESCO Convention on the Means of Prohibiting and Preventing the Illicit Import, Export and Transfer of Ownership of Cultural Property, entered into force on 24 April 1972 and accepted by Australia in 1989;

- the International Covenant on Civil and Political Rights, adopted by the UN General Assembly on 16 December 1966 and in force from 23 March 1976, ratified by Australia on 13 August 1980;

- $\quad$ the International Covenant on Economic, Social and Civil Rights, adopted by the UN General Assembly on 16 December 1966 and in force from 3 January 1976, with ratification by Australia on 10 December 1975;

- $\quad$ the International Labour Organisation Convention (No 169) concerning Indigenous and Tribal peoples in Independent Countries, entered into force on 5 September 1991, but not ratified by Australia;

- $\quad$ the Convention on Biological Diversity (' $C B D$ '), entered into force and ratified by Australia in 1993;

- the International Treaty on Plant Genetic Resources for Food and Agriculture 2001, entered into force in 2004 and ratified by Australia in December 2005;

- the Pacific Regional Framework for the Protection of Traditional Knowledge and Expressions of Culture (2002);

- $\quad$ the Convention for the Safeguarding of the Intangible Cultural Heritage 2003, entered into force on 20 April 2006 but not signed by Australia;

- $\quad$ the United Nations Declaration on the Rights of Indigenous Peoples 2007 ('UNDRIP'), a non-binding declaration endorsed by Australia in 2009.

The UNDRIP specifically recognises the rights and obligations of Indigenous people to their cultural knowledge and practices, and grounds these rights and be implemented. The Northern Territory National Emergency Response Act 2007 (Cth), as part of a package of five statutes, came into effect in August 2007 imposing measures concerning welfare, law enforcement and land tenure in response to allegations of child sex abuse and neglect among Northern Territory Aboriginal communities. Almost a decade before the Intervention, the scope of s 51(xxvi) was the subject of constitutional interpretation by the High Court in Kartinyeri $v$ Commonwealth (1998) 195 CLR 337. The High Court failed to provide a clear majority decision that s 51(xxvi) was only to be utilised for beneficial not detrimental purposes. For a discussion on s 51(xxvi) see Melissa Castan, 'Constitutional Deficiencies in the Protection of Indigenous Rights: Reforming the "Races Power"' (2011) 7(25) Indigenous Law Bulletin 12. 
obligations in the customary laws of their communities. Ruby Langford Ginibi explains the recognition of these rights and obligations in the following terms:

\begin{abstract}
Aboriginal laws were encoded in each group's religious tradition, and were handed down from generation to generation, by word of mouth. They were a part of the oral tradition, passed on by the guardians of that tradition, who gained access to it as they were initiated. All Aboriginal and Torres Strait Islander people were familiar with their own laws and with the daily rights and obligations that were imposed. From early childhood they learnt what the law allowed and what it forbade. They knew both the spiritual dangers and punishments that threatened the law breaker. They witnessed the process by which offenders were punished, cases argued and decided. ${ }^{57}$
\end{abstract}

Under Australian law, the Native Title Act 1993 (Cth) recognises the 'communal, group or individual rights and interests' to land and waters which are based on the observance of traditional customs and traditional laws of Aboriginal and Torres Strait Islander people over the land or waters in question..$^{58}$ Relevantly, however, the legislation does not provide specific protection for those "traditional customs' in a sui generis sense. Rather, the purpose of the legislation is to use those traditional customs and laws as evidence of an applicant's connection to the land and waters in question.

Importantly, it is art 27 of the Universal Declaration of Human Rights which recognises the interconnectedness of intellectual property with cultural and knowledge rights:

(1) Everyone has the right freely to participate in the cultural life of the community, to enjoy the arts and to share in scientific advancement and its benefits.

(2) Everyone has the right to the protection of the moral and material interests resulting from any scientific, literary or artistic production of which he is the author.

Article 27(2) above recognises the Lockean argument in favour of intellectual property rights, ${ }^{59}$ although a similar argument can also apply to the rights of

Ruby Langford Ginibi, 'Aboriginal Traditional and Customary Laws' (1994) 1 Law Text Culture 8, 8. Native Title Act 1993 (Cth) s 223(1).

Lockean theory is based on the premise that a person owns their own body and therefore owns 'the fruits of his own labour'. According to John Locke 'the labour of his body and the work of his hands we may say are properly his. Whatsoever, then, he removes out of the state that nature hath provided and left it in, he hath mixed his own labour with and joined to it something that is his own, and thereby makes it his property': John Locke, Two Treatises on Government (Butler, 1821) Ch.5, §27. Locke's labour theory of property has been used to justify intellectual property rights as natural rights: see Peter Drahos, A Philosophy of Intellectual Property (Dartmouth Publishing, 1996) 41-72; Edwin C Hettinger, 'Justifying Intellectual Property' (1989) 18 Philosophy and Public Affairs 31, 36-7; Justin Hughes, 'The Philosophy of Intellectual Property' (1988) 77 Georgetown Law Journal 287, 296-7; Horacio Spector, 'An Outline of a Theory Justifying Intellectual and Industrial Property Rights' (1989) 8 European Intellectual Property Review 270. For further commentaries on Locke's work see Richard Ashcraft (ed) John Locke: Critical Assessments (Routledge, 1991) (vol 3 contains the discussion on Locke's property theory); C B Macpherson, The Political Theory of Possessive Individualism: Hobbes to Locke (Clarendon Press, 1962); James Tully, A Discourse on Property: John Locke and his Adversaries (Cambridge University Press, 1982). 
Indigenous peoples over their knowledge and cultural expressions. ${ }^{60}$ In fact, this is reinforced by art 15 of the International Covenant on Economic, Social and Civil Rights which provides:

1. The States Parties to the present Covenant recognize the right of everyone:

(a) To take part in cultural life;

(b) To enjoy the benefits of scientific progress and its applications;

(c) To benefit from the protection of the moral and material interests resulting from any scientific, literary or artistic production of which he is the author.

2. The steps to be taken by the States Parties to the present Covenant to achieve the full realization of this right shall include those necessary for the conservation, the development and the diffusion of science and culture.

In the context of Indigenous knowledge and culture, Gathegi explains:

Indigenous peoples ... have over the years developed and built detailed information and knowledge bases on various aspects of their cultures and their natural environment, including detailed knowledge of plant and animal species, soils, seasons and weather patterns. This knowledge is a result of an accumulation of experimentation and experiences over a long period of time, to determine, for instance, that a certain plant has curative or preventive properties over certain diseases. ${ }^{61}$

This would seem to fall within the Lockean view that as effort was expended to develop the knowledge, that knowledge therefore is the property of those who expended the effort to develop it. Although Gathegi suggests further that the Indigenous view is that the property in the knowledge is collective, not private in nature, he notes the pharmaceutical industry's argument that due to the collective nature attributed to traditional knowledge, it must form part of the commons and is therefore available to others (such as pharmaceutical companies) to utilise and produce a new product, the property in which would accrue to the producer. ${ }^{62}$ However, that argument confuses the application of the Lockean argument. If there is a natural right in one's labour - as Locke espouses - then it should not matter whether the right accrues to an individual or a group working on the development of the knowledge, otherwise it would not be possible to have joint ownership of intellectual property. Consequently, it is feasible for the Indigenous community to have a joint right, in line with a communal ownership, over, say, their ecological or medicinal knowledge and so be able to determine how that 
knowledge is used, by whom, and on what terms. ${ }^{63}$ However, as with other forms of intellectual or intangible property, an acknowledgement of such Lockean rights over traditional or Indigenous knowledge requires the establishment of a legislative framework - such as a sui generis regime.

While the 1970 UNESCO Convention on the Means of Prohibiting and Preventing the Illicit Import, Export and Transfer of Ownership of Cultural Property provides a strong regime for the protection against illicit trade in cultural property, it is concerned with tangible property and not intangible property which encompasses the concepts of traditional or Indigenous knowledge and culture. ${ }^{64}$ However, more recent international instruments have made much clearer statements, and proposed more direct obligations to protect the intangible aspects of traditional and Indigenous knowledge and culture. The following will provide a chronological analysis of the relevant instruments and provisions.

\section{A Convention on Biological Diversity}

The third objective of the $C B D$, found in art 1 , is the relevant provision that introduces the concept of the fair and equitable sharing of benefits arising from the utilisation of genetic resources. ${ }^{65}$ It requires that all rights over the genetic resources be taken into account when determining the fair and equitable sharing of benefits arising from the use of those resources. This requires the identification of relevant rights-holders, who, most likely, would include the sovereign nations themselves (as art 3 acknowledges), landowners and Indigenous peoples, bioprospectors, pharmaceutical or biotechnology companies or holders of intellectual property over such resources.

Bioprospectors collect samples of biological material, identifying potentially valuable compounds or attributes for scientific, conservation or commercial purposes. They start the process that leads to the development of technologies from those biological or genetic resources, also referred to as the biodiscovery process. The idea of benefit-sharing espoused in the $C B D$ is relevant when considering the potential economic value and commercial purpose of bioprospecting. As traditional or Indigenous knowledge often assists the bioprospecting process, it is not at all surprising that the issue of benefit-sharing becomes important.

63 Weatherall takes a contrary view when discussing what rights might accrue in relation to traditional designs in Aboriginal art that have been handed down through the generations: Weatherall, above $\mathrm{n}$ 38, 228-9. However, it needs to be recognised that Indigenous or traditional knowledge and culture should not be classified as knowledge that has been static and non-evolving over generations. Rather, as Taubman and Leistner explain, traditional knowledge 'is a form of innovation and creativity, which is essentially dynamic in nature and continues to respond to the evolving needs and shared intellectual life of a community': Antony Taubman and Matthias Leistner, 'Traditional Knowledge' in Silke von Lewinski (ed) Indigenous Heritage and Intellectual Property: Genetic Resources, Traditional Knowledge and Folklore (Kluwer Law International, $2^{\text {nd }}$ ed, 2008) 59, 60.

64 UNESCO Convention on the Means of Prohibiting and Preventing the Illicit Import, Export and Transfer of Ownership of Cultural Property, opened for signature 14 November 1970, 823 UNTS 232 (entered into force 24 April 1972) art 1.

$65 C B D$ art 1. 
In 1996, the then Commonwealth Department of the Environment, Sport and Territories published the National Strategy for the Conservation of Australia's Biological Diversity ('National Strategy'). This document was prepared by the Australian and New Zealand Environment and Conservation Council, a Ministerial Council that existed between 1991 and 2001. The National Strategy focused on Australia's Indigenous biological diversity and attempted to provide a comprehensive and integrated approach to the identification, conservation and management of that biodiversity. ${ }^{66}$ This key policy document had as its goal the protection of 'biological diversity and [maintenance of] ... ecological processes and ... systems' ${ }^{67}$ This included a clear recognition of the contribution and rights of Indigenous peoples over such genetic resources. Nine principles formed the basis of the objectives and actions of the National Strategy, and it is the ninth that is of significance in relation to the recognition of traditional knowledge in the sphere of biodiscovery, namely:

The close, traditional association of Australia's Indigenous peoples with components of biological diversity should be recognised, as should the desirability of sharing equitably benefits arising from the innovative use of traditional knowledge of biological diversity. ${ }^{68}$

Further, Objective 1.8 of the National Strategy required Australia to ' $r \mathrm{r}$ ]ecognise and ensure the continuity of the contribution of the ethnobiological knowledge of Australia's indigenous peoples to the conservation of Australia's biological diversity'. ${ }^{69}$ In doing so, it is also recognised that such knowledge may be privileged or not be in the public domain, ${ }^{70}$ and accordingly, Action item 1.8.2 provided a mechanism by which use of such traditional biological knowledge will be protected and will accrue social and economic benefits to the traditional owners of that knowledge. ${ }^{71}$ Use must only proceed 'with the cooperation and control of the traditional owners of that knowledge'.72 Thereafter, collaborative agreements, which account for existing intellectual property rights, may be used to protect the use of traditional biological knowledge. ${ }^{73}$ Further, a royalty payment system may be established, where there are commercial developments using that traditional knowledge..$^{74}$ Objective 2.8 on access to genetic resources specifically notes Action item 1.8.2 in reference to the issue of property rights over such resources given that the aim is to "[e]nsure that the social and economic benefits of the use of genetic material and products derived from Australia's biological diversity accrue to Australia'.75 The National Strategy could be

National Strategy 6-9 <www.environment.gov.au/archive/biodiversity/publications/strategy/index. html>.

\section{Ibid 10.}

Ibid 11 .

Ibid 21.

Ibid.

Ibid 22.

Ibid.

Ibid.

Ibid.

Ibid 34-5. 
interpreted as having paved the way for the formal recognition and protection of traditional biological knowledge. However, that has not occurred other than as part of a benefit-sharing agreement required under the regulations for permits to access genetic resources on Commonwealth land (the Environment Protection and Biodiversity Conservation Act 1999 (Cth) ('EPBC Act') will be discussed in further detail below on this point).

Objective 4.1 of the National Strategy is to assist effective conservation and management through a knowledge and understanding of Australia's biodiversity. ${ }^{76}$ Action item 4.1.8 notes the value of ethno-biological knowledge and seeks to incorporate the knowledge and practices of Aboriginal and Torres Strait Islander peoples in conservation programs and biodiversity research. ${ }^{77}$ This implies the need to record such knowledge — but this should be done with the approval and involvement of the relevant Indigenous community, ${ }^{78}$ along with an equitable sharing of the potential benefits of the knowledge and practices. ${ }^{79}$

Of the priorities under the National Strategy to be achieved by the year 2000, the second priority confirms the expectation that engagement with and protection of the ethno-biological knowledge of Aboriginal and Torres Strait Islander peoples will be implemented under cooperative programs. ${ }^{80}$ The National Strategy was reviewed in 2001 with a finding that Objective 1.8 was considered not to have been achieved - despite the various programs in place in many of the states and territories, and despite the establishment of the Indigenous Advisory Committee under the Commonwealth's EPBC Act. ${ }^{81}$ One of the key principles underpinning Australia's Biodiversity Conservation Strategy for 2010-2030 is the need to 'acknowledge and respect the culture, values, innovations, practices and knowledge of Indigenous peoples' ${ }^{82}$ Accordingly, one of the priorities is the increased engagement of Indigenous people along the following terms:

Indigenous peoples have a special connection and relationship with Australia's natural environments. Accordingly, the important role of Indigenous traditional ecological knowledge in conserving Australia's biodiversity needs to be more actively promoted to other biodiversity managers. This transfer of knowledge needs to be two-way - it is also important that Indigenous peoples have access to scientific knowledge and best practice for natural resource management. In addition, traditional

76 Ibid 45.

77 Ibid $47-8$

78 Ibid 48.

79 Ibid.

80 Ibid 55, Action point 7.1.1(b).

81 Australian and New Zealand Environment and Conservation Council, 'Review of The National Strategy for the Conservation of Australia's Biological Diversity' (Australian Government, Department of Environment, 2001) app A <http://www.environment.gov.au/resource/reviewnational-strategy-conservation-australias-biological-diversity $>$.

82 Natural Resource Management Ministerial Council, 'Australia's Biodiversity Conservation Strategy 2010-2030' (Australian Government, Department of Sustainability, Environment, Water, Population and Communities, 2010) $16<$ https://www.environment.gov.au/system/files/resources/58321950f8b6-4ef3-bb68-6f892420d601/files/biodiversity-strategy-2010.pdf>. 
ecological knowledge is continually evolving and Indigenous peoples need support for the recording, ongoing development and intergenerational transfer of Indigenous knowledge. ${ }^{83}$

This implies that the knowledge flows from the Indigenous community - and the knowledge flow and 'support' back to the Indigenous community satisfy the requisite benefit-sharing obligation under the $C B D$. This may well be in keeping with the third objective of the $C B D$, but that objective must be read in conjunction with those provisions of the $C B D$ that enable the Contracting Parties, ie the nations, to take control over the same genetic resources. The sovereign rights of states over their natural resources are recognised in art 3 of the $C B D$, and include the authority of those states to determine access to genetic resources using national legislation. This is recognised in art 15 para 1:

Recognising the sovereign rights of States over their natural resources, the authority to determine access to genetic resources rests with the national governments and is subject to national legislation.

In particular, art 15 para 7 requires that each Contracting Party 'take legislative, administrative or policy measures, as appropriate' for the fair and equitable sharing of benefits 'arising from the commercial and other utilisation of genetic resources with the Contracting Party providing such resources'. Such measures would seem to extend the use of traditional knowledge as art 8(j) makes clear that a nation will:

Subject to its national legislation, respect, preserve and maintain knowledge, innovations and practices of indigenous and local communities embodying traditional lifestyles relevant for the conservation and sustainable use of biological diversity and promote their wider application with the approval and involvement of the holders of such knowledge, innovations and practices and encourage the equitable sharing of the benefits arising from the utilization of such knowledge, innovations and practices. ${ }^{84}$

Further, art $10(\mathrm{c})$ of the $C B D$ encourages customary uses and the protection of such uses of biological resources in line with traditional practice. Article 18(4) also requires Contracting Parties to 'encourage and develop methods of cooperation for the development and use of technologies, including indigenous and traditional technologies'.

The $C B D$ recognises the influence of patents and other intellectual property rights, and requires 'that such rights are supportive of and do not run counter to' the objectives of the $C B D .{ }^{85}$ Further, the developments in relation to art $8(\mathrm{j})$ include a focus on the benefit-sharing requirements in that provision. Part of this process emphasises the need for prior informed consent on mutually agreed terms for such benefit-sharing arrangements to be valid. 
The issue of prior informed consent revolves around the question of how the knowledge will be used. An obvious point is of course that use of traditional or Indigenous knowledge - whether it be in environmental resource management, health practices, and/or for medicinal purposes - must be respectful of the dominant values of the relevant Indigenous group/s. Custodianship must be recognised - and with that the interlinking issue of prior informed consent. Further, it needs to be recognised that the knowledge-holders themselves have obligations under customary law with respect to the preservation and use of the knowledge, and how that knowledge is passed on to future generations. Accordingly, those seeking to use that knowledge outside the community must obtain prior informed consent from the custodians, and in order to do so protocols of engagement are required to ensure that due process is followed.

This then leads to the second element of determining mutually agreed terms to ensure that the benefit flows to the community of the knowledge-holders from the use of that knowledge by third parties such as bioprospectors, researchers, and investors. The $C B D$ has provided for the components of prior informed consent, ${ }^{86}$ and benefit-sharing and mutually agreed terms, ${ }^{87}$ and these elements have subsequently been the subject of much discussion and debate among the parties to the $C B D$. The result of this has been the development of the Bonn Guidelines to assist with determining access and benefit-sharing arrangements, ${ }^{88}$ and more recently the Nagoya Protocol (discussed below) ${ }^{89}$

\section{B CBD: The Nagoya Protocol}

The Nagoya Protocol is a supplementary agreement to the $C B D$ and is directed at improving legal certainty, transparency and compliance with benefit-sharing mechanisms. It applies to genetic resources that are covered by the $C B D$, and its objectives centre around the fair and equitable sharing of benefits arising from the utilisation of genetic resources. Australia signed the Nagoya Protocol on 20 January 2012 but has not yet ratified it. ${ }^{90}$ The federal Government has however released a model with respect to intended implementation of the Nagoya Protocol

86 Ibid art 15(5)

87 Ibid art 15(4).

88 Bonn Guidelines on Access to Genetic Resources and Fair and Equitable Sharing of the Benefits Arising out of their Utilisation, COP 6 Decision VI/24, Conference of the Parties, Convention on Biological Diversity <www.cbd.int/decision/cop/?id=7198> ('Bonn Guidelines').

89 Nagoya Protocol on Access to Genetic Resources and the Fair and Equitable Sharing of Benefits Arising from their Utilization to the Convention on Biological Diversity, opened for signature 2 February 2011 (entered into force 12 October 2014) ('Nagoya Protocol').

90 Convention on Biological Diversity, Parties to the Nagoya Protocol <https://www.cbd.int/abs/ nagoya-protocol/signatories/>. For further detail on Australia relevant to the $C B D$ see Australia - Country Profile, Convention on Biological Diversity <https://www.cbd.int/countries/default. shtml?country=au>. 
in Australia. ${ }^{91}$ While Australia has not yet ratified the Nagoya Protocol, an overview of its purpose and operation is given below because of its significance.

The Nagoya Protocol explicitly covers traditional knowledge associated with genetic resources covered by the $C B D$ and the benefits arising from their utilisation..$^{92}$ Contracting parties are required to take measures to ensure Indigenous and local communities' prior informed consent and equitable benefit-sharing within the context of community laws and procedures, including customary use and exchange. The text of the Nagoya Protocol contains a number of provisions dealing with traditional knowledge, including various references to art 8(j) of the $C B D$ (discussed above), the inseparable interrelationship between genetic resources and traditional knowledge, the diversity of circumstances in which traditional knowledge is owned or held (including by states), the identification of the rightful holders of traditional knowledge, and the UNDRIP and the principle of the non-extinguishment of existing rights.

The Nagoya Protocol sets out obligations for contracting parties to take measures in relation to access to genetic resources, benefit-sharing, and compliance. Domestic-level access obligations include providing clear rules and procedures for prior informed consent and on mutually agreed terms, such as issuing permits (or equivalents) when access is granted. Domestic-level benefit-sharing measures include monetary and non-monetary benefits - such as royalties and the sharing of research results. Compliance obligations include requiring contracting parties to take measures so that genetic resources utilised within their jurisdiction have been accessed in accordance with prior informed consent and on mutually agreed terms, and in cases of alleged violation ensure opportunities are available for legal recourse. Contracting parties are also required to take steps to monitor the utilisation of genetic resources after they leave a country by establishing effective checkpoints at various stages: research, development, innovation, precommercialisation, commercialisation, and so on.

A range of mechanisms are provided in the Nagoya Protocol to assist contracting parties with implementation, including: the 'Access and Benefit-sharing ClearingHouse' for exchanging information on access and benefit-sharing (as stipulated by art 14 of the Nagoya Protocol and art 18(3) of the CBD); establishing national focal points and competent national authorities to provide information, grant access, and co-operate on issues relating to compliance; and developing research capability and institutions for contracting parties for the purposes of technology transfer and awareness-raising, inter alia.

91 Australian Government, Department of the Environment, The Nagoya Protocol - Convention on Biological Diversity <http://www.environment.gov.au/topics/science-and-research/australiasbiological-resources/nagoya-protocol-convention-biological $>$. See also Allens Linklaters, Focus: Australia Releases Model for Implementing the Nagoya Protocol (8 May 2014) <http://www.allens. com.au/pubs/ip/foip8mayl4.htm>.

92 For further detail see Convention on Biological Diversity, The Nagoya Protocol on Access and Benefit-Sharing and Traditional Knowledge $<$ https://www.cbd.int/traditional/Protocol.shtml $>$. 


\section{International Treaty on Plant Genetic Resources for Food and Agriculture}

A related treaty to the $C B D$ is the International Treaty on Plant Genetic Resources for Food and Agriculture. ${ }^{33}$ This treaty is concerned with the conservation and sustainable use of plant genetic resources for food and agriculture, fair and equitable sharing of the benefits arising from their use and harmony with the $C B D$ for sustainable agriculture and food security. The contribution of local and Indigenous communities and farmers is recognised under the treaty. ${ }^{94}$ This has created an obligation to 'take measures to protect and promote farmers' rights, including the protection of traditional knowledge relevant to plant genetic resources for food and agriculture' and the right to share in the benefits and to participate in decision-making regarding 'the conservation and sustainable use of plant genetic resources for food and agriculture'. ${ }^{95}$

\section{Regional Framework for the Protection of Traditional Knowledge and Expressions of Culture}

This framework was established as part of a joint effort between the Secretariat of the Pacific Community, the Pacific Islands Forum Secretariat and the UNESCO Pacific Regional Office. Members of the forum are Australia, the Cook Islands, the Federated States of Micronesia, Fiji, Kiribati, Nauru, New Zealand, Niue, Palau, Papua New Guinea, the Republic of Marshall Islands, Samoa, the Solomon Islands, Tonga, Tuvalu and Vanuatu. The framework provides the Model Law for the Protection of Traditional Knowledge and Expressions of Culture 2002 ('Model $L a w^{\prime}$ ), establishing traditional cultural rights (ss 6-12) and moral rights (s 13) over such knowledge and expressions, the need for prior informed consent (pt 4) as discussed above, a regime for applications for use and identifying the traditional owners (ss 15-19), authorised user agreements (ss 20-4), an enforcement regime covering civil and criminal actions and defences (ss 26-34) and finally a Cultural Authority to oversee the entire regime (ss 36-7). ${ }^{96}$ The Model Law has so far been used as a guide by two island nations - Fiji and Palau - for the purposes of developing sui generis legislation to protect traditional knowledge and cultural expressions. While six nations have been recognised for taking 'commendable steps to implement the Model Law', draft Bills have been made available for

93 International Treaty on Plant Genetic Resources for Food and Agriculture, opened for signature 3 November 2001 (entered into force 29 June 2004).

94 Ibid art 9.1 .

95 Ibid art 9.2.

96 Secretariat of the Pacific Community, Pacific Islands Forum Secretariat and UNESCO Pacific Regional Office, Regional Framework for the Protection of Traditional Knowledge and Expressions of Culture (2002) <http://www.forumsec.org.fj/resources/uploads/attachments/documents/PacificM odelLaw,ProtectionofTKandExprssnsofCulture20021.pdf>. 
public consultation in Fiji and Palau (and the Cook Islands also introduced a Bill for Traditional Knowledge in 2014). ${ }^{97}$

\section{E Convention for the Safeguarding of the Intangible Cultural Heritage}

This UNESCO convention, entered into force on 20 April 2006, recognises 'the importance of the intangible cultural heritage as a mainspring of cultural diversity and a guarantee of sustainable development ${ }^{\prime}{ }^{98}$ There are 161 states party to the ICH Convention (at 15 May 2014). However, Australia and various other Western nations - including New Zealand, Canada, the United States of America, and the United Kingdom — are not a party to the ICH Convention. ${ }^{99}$

Article 1 of the $\mathrm{ICH}$ Convention outlines its purpose: safeguarding and ensuring respect for the intangible cultural heritage of relevant communities, groups and individuals; raising awareness at the local, national, and international levels of the importance of intangible cultural heritage; providing international cooperation and assistance for the protection of intangible cultural heritage. A definition for 'intangible cultural heritage' is provided in art 2 para 1 of the ICH Convention:

The 'intangible cultural heritage' means the practices, representations, expressions, knowledge, skills - as well as the instruments, objects, artefacts and cultural spaces associated therewith - that communities, groups and, in some cases, individuals recognize as part of their cultural heritage. This intangible cultural heritage, transmitted from generation to generation, is constantly recreated by communities and groups in response to their environment, their interaction with nature and their history, and provides them with a sense of identity and continuity, thus promoting respect for cultural diversity and human creativity. For the purposes of this Convention, consideration will be given solely to such intangible cultural heritage as is compatible with existing international human rights instruments, as well as with the requirements of mutual respect among communities, groups and individuals, and of sustainable development.

The scope of 'intangible cultural heritage' is outlined in art 2 para 2 of the $I C H$ Convention: Knowledge\%20Action\%20Plan\%202009.pdf>.

98 Convention for the Safeguarding of the Intangible Cultural Heritage, opened for signature 17 October 2003, 2368 UNTS 1 (entered into force 20 April 2006) ('ICH Convention').

99 An alliance that appears again in relation to the UNDRIP. It is worthwhile to note that the Australian Human Rights Commission recommended that Australia ratify the ICH Convention. For further details see Australian Human Rights Commission, 'Ratification of 2003 UNESCO Convention for the Safeguarding of Intangible Cultural Heritage', Submission to Department of Environment, Water, Heritage and the Arts, Inquiry into the Ratification of the 2003 UNESCO Convention Safeguarding Intangible Cultural Heritage, 24 September 2008, $3<$ https://www.humanrights.gov.au/submissionratification-2003-unesco-convention-safeguarding-intangible-cultural-heritage-2008\#Heading166>. 
The 'intangible cultural heritage', as defined in paragraph 1 above, is manifested inter alia in the following domains:

(a) oral traditions and expressions, including language as a vehicle of the intangible cultural heritage;

(b) performing arts;

(c) social practices, rituals and festive events;

(d) knowledge and practices concerning nature and the universe;

(e) traditional craftsmanship.

While this combined definition provides some insight into defining traditional or Indigenous knowledge and culture, there are of course a plethora of definitions for the terms traditional knowledge, Indigenous knowledge, Indigenous ecological knowledge, traditional medicinal knowledge, traditional cultural expression and so on. A number of disparate groups (such as Indigenous communities/bodies, global organisations and associations, academics and research institutes, and so on) have devoted considerable time and energy into developing these definitions. ${ }^{100}$ WIPO published a report in this area in 2001 (based on its fact-finding missions on intellectual property and traditional knowledge in 1998-1999). ${ }^{101}$ Indeed, when compared to these earlier reports, WIPO's later work has proven to be more nuanced as it approaches the final stages of drafting model laws for traditional cultural expressions and traditional knowledge. ${ }^{102}$

The meaning of 'safeguarding' is defined in art 2 of the ICH Convention ${ }^{103}$ although the full scope of the meaning becomes apparent when considering the domestic-level obligations of states parties. In the process of ensuring intangible cultural heritage in its territory is safeguarded, a state party is to 'identify and define the various elements of the intangible cultural heritage present in its territory, with the participation of communities, groups and relevant non-governmental organizations'. ${ }^{104}$ In order to achieve this it is expected that appropriate inventories are created, regularly updated and reported ${ }^{105}$ to the intergovernmental committee established under the ICH Convention. ${ }^{106}$ Further, states parties are to endeavour

100 See, eg, Robynne Quiggin, 'Protecting Culture' in Larissa Behrendt, Chris Cunneen and Terri Libesman (eds), Indigenous Legal Relations in Australia (Oxford University Press, 2009) 207, 209 210; Stoianoff, 'Navigating the Landscape of Indigenous Knowledge', above n 5, 23-25; Taubman and Leistner, above $\mathrm{n} 63,68-81$.

101 'Intellectual Property Needs and Expectations of Traditional Knowledge Holders: WIPO Report on Fact-Finding Missions on Intellectual Property and Traditional Knowledge (1998-1999)' (WIPO, April 2001).

102 See, eg, WIPO Intergovernmental Committee, The Protection Of Traditional Cultural Expressions: Draft Gap Analysis, 13th sess, WIPO/GRTKF/IC/13/5(b) Rev (11 October 2008).

103 ICH Convention art 2.3: "Safeguarding" means measures aimed at ensuring the viability of the intangible cultural heritage, including the identification, documentation, research, preservation, protection, promotion, enhancement, transmission, particularly through formal and non-formal education, as well as the revitalization of the various aspects of such heritage.'

104 Ibid art 11.

105 Ibid art 12.

106 Ibid art 5. The functions of the Intergovernmental Committee are provided at art 7. 
to promote the function of tangible cultural heritage in society and integrate the safeguarding of the heritage in planning programs; establish or designate one or more competent bodies for safeguarding the heritage; foster scientific, technical and artistic studies for the safeguarding of intangible cultural heritage; and adopt legal, technical, administrative and financial measures for:

i. fostering the creation or strengthening of institutions for training in the management of the intangible cultural heritage and the transmission of such heritage through forums and spaces intended for the performance or expression thereof;

ii. ensuring access to the intangible cultural heritage while respecting customary practices governing access to specific aspects of such heritage;

iii. establishing documentation institutions for the intangible cultural heritage and facilitating access to them. ${ }^{107}$

The ICH Convention also requires states parties to engage in education, awarenessraising and capacity-building (art 14), engage in international cooperation and assistance (pt V), contribute to the Intangible Cultural Heritage Fund (art 26(1)) and provide regular progress reports to the intergovernmental committee (art 29).

\section{F United Nations Declaration on the Rights of Indigenous People}

The UNDRIP is a non-binding document adopted by the General Assembly on 13 September 2007, by a vote of 144 in favour, four against and 11 abstained. Australia, Canada, New Zealand and the United States all voted against the text, concerned about the obligations for compensation and/or self-determination that might follow. Since then, however, Australia endorsed the UNDRIP in April 2009, with New Zealand endorsing the UNDRIP a year later, Canada in November 2010 and the US in December 2010. However, that does not mean that steps have been taken to ratify the UNDRIP. Nonetheless, endorsement does indicate a political will to take those steps, and can only reinforce Australia's international obligations with respect to providing an adequate regime to protect, preserve and utilise Indigenous knowledge, culture and practices. The UNDRIP Preamble states:

Recognising that respect for Indigenous knowledge, cultures and traditional practices contributes to sustainable and equitable development and proper management of the environment.

Specifically, art 11 of the UNDRIP recognises the right of Indigenous people 'to practise and revitalise their cultural traditions and customs'. This extends to 'the right to maintain, protect and develop the past, present and future manifestations of their cultures, such as archaeological and historical sites, artefacts, designs, 
ceremonies, technologies and visual and performing arts and literature'. ${ }^{108}$ The expectation is that the state will develop, with the participation of Indigenous peoples, effective compensation mechanisms 'with respect to their cultural, intellectual, religious and spiritual property taken without their free, prior and informed consent or in violation of their laws, traditions and customs'. ${ }^{109}$

A clear link is made with the $C B D$ in art 24.1 of the UNDRIP, which provides: 'Indigenous peoples have the right to their traditional medicines and to maintain their health practices, including the conservation of their vital medicinal plants, animals and minerals'. Article 31 of the UNDRIP is perhaps the most significant provision, which, if implemented, will in many ways reflect the work of the WIPO Intergovernmental Committee that has been investigating and drafting provisions for the protection of traditional knowledge and traditional cultural expressions for over a decade:

1. Indigenous peoples have the right to maintain, control, protect and develop their cultural heritage, traditional knowledge and traditional cultural expressions, as well as the manifestations of their sciences, technologies and cultures, including human and genetic resources, seeds, medicines, knowledge of the properties of fauna and flora, oral traditions, literatures, designs, sports and traditional games and visual and performing arts. They also have the right to maintain, control, protect and develop their intellectual property over such cultural heritage, traditional knowledge, and traditional cultural expressions. (emphasis added)

2. In conjunction with Indigenous peoples, States shall take effective measures to recognise and protect the exercise of these rights.

The authors submit that art 31 of the UNDRIP is the direction that Australia should now be taking. There are already several nations and regions around the world that have adopted legislative regimes to accommodate such rights as provided for in art 31. Nations which have adopted sui generis legislation - requiring the establishment of registers or databases and a representative authority of some kind - for the purpose of protecting Indigenous knowledge include Brazil, Peru, Panama, and the Philippines. Some models are based on the Model Provisions for National Laws on the Protection of Expressions of Folklore Against Illicit Exploitation and Other Prejudicial Action (UNESCO and WIPO, 1982), which contain intellectual property rights-type provisions. More recently, the Pacific Regional Framework for the Protection of Traditional Knowledge and Expressions of Culture (discussed above) has been used as a template. Other manifestations of sui generis legislation are found in Africa, the Andean Community of Nations (formerly the Andean Pact Nations) and ASEAN. What is important about the ICH Convention and the UNDRIP is the underlying commitment to human rights 
ideals and to ensuring that cultural practices which violate those ideals will not be sanctioned under these instruments. ${ }^{110}$

The authors suggest that the international obligations discussed above make it clear that there is an expectation that the protection of traditional or Indigenous knowledge must be in conjunction with Indigenous laws, traditions and customs. Prior informed consent is essential in any dealing, and engagement must be on mutually agreed terms. The access and benefit-sharing arrangement must pay heed to the Bonn Guidelines, and anticipate the implementation of the Nagoya Protocol. As discussed earlier, the Nagoya Protocol contains a range of tools and mechanisms to assist contracting parties with implementing access and benefitsharing schemes on mutually agreed terms — which the authors submit align closely with the underlying aims of art 31 of the UNDRIP. Indeed, this is now well-canvassed territory internationally, and Australia would certainly not need to 'reinvent the wheel' for the purposes of implementing domestic sui generis legislation for the protection Indigenous knowledge and culture. Development of databases or registers of Indigenous knowledge and culture are essential for the successful operation of benefit-sharing regimes, and relevant competent authorities are also necessary for the administration of those regimes. Before considering what shape such protection would take in Australia, the following section considers what is currently protected under the Commonwealth of Australia.

\section{WHAT HAS BEEN IMPLEMENTED IN AUSTRALIA TO DATE}

\section{A Tangible Heritage}

For some decades, the tangible aspects of Aboriginal and Torres Strait Islander heritage have received protection both at state and federal level. The following three pieces of legislation fall under the category of heritage protection providing protection for items associated with tangible space and objects.

\section{Aboriginal and Torres Strait Islander Heritage Protection Act}

Each state and territory has their own heritage legislation, whether sui generis, or as part of a more general environment and planning regime. The Aboriginal and Torres Strait Islander Heritage Protection Act 1984 (Cth) ('ATSIHP Act') was introduced to enable the federal Government 'to take legal action where State

110 For example, see the definition of 'intangible cultural heritage' in the ICH Convention: art 2(1)(2); UNDRIP art 46(1). See further Christoph Antons, 'The International Debate about Traditional Knowledge and Approaches in the Asia-Pacific Region' in Christoph Antons (ed), Traditional Knowledge, Traditional Cultural Expressions and Intellectual Property Law in the Asia-Pacific Region (Kluwer Law International, 2009) 39, 47. 
or Territory laws were inadequate, not enforced or non-existent'. ${ }^{111}$ It was 'not intended to be an alternative to land claim procedures'. ${ }^{112}$ Section 4 outlines the purpose of the Act:

the preservation and protection from injury or desecration of areas and objects in Australia and in Australian waters, being areas and objects that are of particular significance to Aboriginals in accordance with Aboriginal tradition.

The focus of the ATSIHP Act is dealing with developers who want to develop land that is significant to an Indigenous community. Significantly, the ATSIHP Act recognises the connection between cultural identity and the land, and its aim is to prevent damage to Indigenous cultural heritage caused by the activities of land users and/or developers. Interested parties can seek a declaration from the Minister to protect or preserve a specified area from injury or desecration by a proposed activity. However, the scope is limited to significant Indigenous areas or objects.

\section{Protection of Movable Cultural Heritage Act}

The Protection of Movable Cultural Heritage Act 1986 (Cth) implements Australia's obligations under the 1970 UNESCO Convention on the Means of Prohibiting and Preventing the Illicit Import, Export and Transfer of Ownership of Cultural Property. It regulates the movement in and out of Australia of culturally significant objects. To qualify, the object must: be an object of cultural significance to Aboriginal and Torres Strait Islander people or be made by Aboriginal and Torres Strait Islander people; not be created specifically for sale; be at least 30 years old and not adequately represented in Aboriginal and Torres Strait Islander community collections, or public collections in Australia. ${ }^{113}$ This implies that if there are 'adequate' representations of a culturally significant object in Australian collections then it is possible to export other such items.

\section{Environment Protection and Biodiversity Conservation Act}

In addition to the access provisions, the EPBC Act establishes the National Heritage List and the Commonwealth Heritage List. Both include natural, Indigenous and historic places identified as having heritage values. The Australian Heritage Council was established to include Indigenous members, and one task of the Council is to identify Indigenous people with rights and interests in relation to a place being considered for listing. There is also an Indigenous Advisory Committee to assist the Minister in regard to the EPBC Act generally. The Indigenous Heritage Program promotes Indigenous heritage values important to Aboriginal and Torres Strait Islander people through projects that

111 Commonwealth, Parliamentary Debates, House of Representatives, 9 May 1984, 2129 (Clyde Holding).

112 Ibid.

113 Protection of Movable Cultural Heritage Regulations 1987 (Cth), sch 1 pt 1. 
teach traditional knowledge and customary responsibilities in relation to land and waters (and other heritage places), and promotes the development of traditional knowledge databases.

\section{B Intangible Cultural Expressions}

Traditional cultural expressions such as expressions of folklore, Indigenous art and handicrafts and music and performance have received protection under the Australian Copyright Act 1968 (Cth) — albeit to a limited extent. The outcomes of the copyright cases of the 1990s discussed above in Part II make it plain that while individual Indigenous artists can easily be afforded protection under the Act, the communities to which the artist is responsible cannot. What this series of cases demonstrates is a clear inability of Australian copyright law to deal with the collective nature of traditional cultural expressions and knowledge, and reinforces its ineptness to accommodate customary law unless there is a specific provision to allow for it. This clearly emphasises the need for sui generis legislation for the protection of such customary and communal expressions and knowledge. This remains the case even though the folklore provisions of the Copyright Act 1968 (Cth) provided some recognition. These provisions were made available due to the Australia-United States Free Trade Agreement (entered into force on 1 January 2005), and were achieved through the definition of 'live performance'. The performer of the expression of folklore becomes a joint owner with the maker of the sound recording - acquiring moral rights in his/her performance — and is able to exercise performers' protection for a live performance. ${ }^{114}$ While not a collective right, it does provide some protection for storytelling by the performers - although it must be kept in mind that it is jointly owned with the recorder of the performance.

\section{Knowledge}

The issue of the extent of protection that Australian patent law can provide for Indigenous knowledge is an interesting question. Section 18(1) of the Patents Act 1990 (Cth) defines a patentable invention as one that is a manner of manufacture that is novel, contains an inventive step and is useful. This raises the issue of whether Indigenous knowledge - for example, biological resources - can satisfy the validity requirements of novelty, inventiveness and utility. Further, does Indigenous knowledge prevent patentability on the basis that the information forms part of the prior art base from which the criteria of novelty is judged?

There has been much international discussion on the introduction of a disclosure provision in patent and plant variety legislation, and this has been accounted for 
in the WIPO draft articles for the protection of traditional knowledge. ${ }^{115}$ Such a disclosure would require patent applicants to disclose where they obtained the biological material and associated traditional knowledge used in the invention, including whether prior informed consent for access and use was obtained. ${ }^{116} \mathrm{~A}$ number of countries have introduced such a provision - such as China in its patent legislation since 2008 - while Australia is yet to follow suit.

If the Indigenous knowledge is secret and complies with the rules of confidentiality then it may not form part of the prior art base and thereby novelty is maintained. If the knowledge forms one or more significant components of the invention developed from the biological resource, then the providers of that knowledge may have a claim as joint owners of the ensuing patent. There are two examples that prove this can be done. Indigenous community engagement with biodiversity research that has led to patents for medicinal inventions are: the Chuulangun Aboriginal Corporation in Cape York, Queensland and the Jarlmadangah Burru Aboriginal Corporation in the Kimberley Region, Western Australia. The Chuulangun Aboriginal Corporation has a collaborative research project with researchers from the 'Quality Use of Medicines and Pharmacy Research Centre' at the University of South Australia examining the pharmacological activities of some traditional medicinal plants. Two International Patent Co-operation Treaty Applications were made, one in relation to anti-inflammatory compounds, ${ }^{117}$ and the other for an anti-inflammatory extract, ${ }^{118}$ and in both instances the inventors listed included the Indigenous elder from the community. The Jarlmadangah Burru Community utilised knowledge of native plants in the treatment of pain for its research partnership. The Marjala plant is used to produce an ointment for wounds, or can be ingested in liquid form to treat joint pain. ${ }^{119}$ Griffith University in the state of Queensland formed an equal partnership with the Jarlmadangah Burru Community to determine the bioactive chemical and its pain relief qualities,

115 WIPO Intergovernmental Committee, The Protection of Traditional Knowledge: Draft Articles, $28^{\text {th }}$ sess, WIPO/GRTKF/IC/28/5 (2 June 2014). See also Conference of the Parties, Convention on Biological Diversity, Decision VII/19: Access and Benefit-Sharing as Related to Genetic Resources $\mathrm{UNEP} / \mathrm{CBD} / \mathrm{COP} / \mathrm{DEC} / \mathrm{VII} / 19$ (13 April 2004): interrelation of access to genetic resources and disclosure requirements in IP rights applications.

116 Conference of the Parties, Convention on Biological Diversity, Decision VII/19: Access and BenefitSharing as Related to Genetic Resources UNEP/CBD/COP/DEC/VII/19 (13 April 2004): interrelation of access to genetic resources and disclosure requirements in IP rights applications.

117 Susan Jean Semple, Bradley Scott Simpson, Ross Allan McKinnon, David Claudie, Petrus Jacobus Gerber, Jiping Wang and George Moreton, 'Anti-Inflammatory Compounds', International Patent Application: PCT/AU2010/001502 (University of South Australia and Chuulangun Aboriginal Corporation) (10 November 2010).

118 Susan Jean Semple, Bradley Scott Simpson, David Claudie, Jiping Wang, Nicholas Smith and Ross Allan McKinnon, 'Anti-Inflammatory Extract', International Patent Application: PCT/ AU2010/001497 (University of South Australia and Chuulangun Aboriginal Corporation) ) (10 November 2010).

119 IP Australia, Nanga Mai Arung Dream Shield: A Guide to Protecting Designs, Brands and Inventions for Aboriginal and Torres Strait Islanders, (Australian Government, 2010) 31. 
culminating in a successful joint application for a patent. ${ }^{120}$ These arrangements would seem to follow the benefit-sharing obligations placed upon bioprospectors seeking an access permit for genetic resources under the EPBC Act (discussed above and further below).

\section{EPBC Act}

Regulations for the access provisions in s 301 of the $E P B C$ Act were implemented on 1 December 2005 and form pt 8A of the Environment Protection and Biodiversity Conservation Regulations 2000 (Cth) ('EPBC Regulations'). The purpose of these regulations is provided in reg 8A.01, which emphasises the nationally consistent approach to accessing biological resources in Australia, 'ensuring the equitable sharing of the benefits arising from the use of biological resources'121 in Commonwealth areas, and 'recognising the special knowledge held by indigenous persons about biological resources'. ${ }^{122}$

Permits are required to access biological resources, ${ }^{123}$ but only access for commercial or potentially commercial purposes will require a benefit-sharing agreement. ${ }^{124}$ This must then be obtained with the prior informed consent of the owner of the land - where that land is Indigenous people's land - and where the access provider is the owner of that land. ${ }^{125}$ Benefit-sharing agreements must provide for the recognition, protection and valuing of any Indigenous people's knowledge that will be used as part of the access. ${ }^{126}$ Among the other details, the benefit-sharing agreement must include:

(h) a statement regarding any use of indigenous people's knowledge, including details of the source of the knowledge ...

(i) a statement regarding benefits to be provided or any agreed commitments given in return for the use of the indigenous people's knowledge;

(j) if any indigenous people's knowledge of the access provider, or other group of indigenous persons, is to be used, a copy of the agreement

120 Ibid. For an overview of the arrangements between the Jarlmadangah Burru Community and Griffith University see Sarah Holcombe and Terri Janke, 'Patenting the Kakadu Plum and the Marjarla Tree: Biodiscovery, Intellectual Property and Indigenous Knowledge' in Matthew Rimmer and Alison McLennan (eds), Intellectual Property and Emerging Technologies: The New Biology (Edward Elgar Publishing, 2012) 293, 311-14.

121 EPBC Regulations reg 8A.01(b).

122 Ibid reg 8A.01(c).

123 Ibid reg 8A.06.

124 Ibid reg 8A.07.

125 Ibid reg 8A.10, 17.03A(6)(a). This addresses one of the suggestions made by the Commonwealth Department of Agriculture, Fisheries and Forestry that benefit-sharing agreements be contingent on the commercialisation of the materials accessed. See further Natalie Stoianoff, 'The Recognition of Traditional Knowledge under Australian Biodiscovery Regimes: Why Bother with Intellectual Property Rights?' in Christoph Antons (ed), Traditional Knowledge, Traditional Cultural Expressions and Intellectual Property Law in the Asia-Pacific Region (Kluwer Law International, 2009) 304. 
regarding use of the knowledge (if there is a written document), or the terms of any oral agreement, regarding the use of the knowledge. ${ }^{127}$

The applicant seeking an access permit must recognise and provide evidence of agreements to use the traditional knowledge of not only an access provider, but also other groups of Indigenous persons providing information in relation to the biological resource for which access is being sought. This is clearly in line with Australia's obligations under arts 8(j), 10(c) and 18(4) of the $C B D$. However, a cursory glance at the National Parks Australia website shows a relatively small number of permits being granted for commercial purposes - the majority are for non-commercial purposes and accordingly do not require a benefit-sharing agreement. ${ }^{128}$ It should also be noted that this regime only covers Commonwealth areas. That means that state areas and privately held land are the subject of different regulations (if any). ${ }^{129}$ Further, it is important to note that this regime only invokes regard for Indigenous knowledge where that knowledge was sought or obtained in relation to the desire to access a particular biological resource..$^{130}$

\section{Queensland Biotechnology Code of Ethics}

While the state of Queensland has its own access and benefit-sharing regime the Biodiscovery Act 2004 (Qld) - this legislation does not consider the use of traditional or Indigenous knowledge in its access or benefit-sharing provisions. This has been left to the Queensland Biotechnology Code of Ethics 2006 ('Code'). The Code is mandatory for three types of organisations:

(a) Queensland Government agencies, research centres, laboratories and public hospitals that conduct biotechnological activities;

(b) private sector companies, academic institutions and research bodies that receive financial assistance from the Queensland Government to undertake biotechnological activities; and

(c) co-operative research centres (CRCs) that receive financial assistance from the Queensland Government to undertake biotechnological activities, and all CRCs that conduct biotechnological activities that have a Queensland Government body or officer as a participating member. ${ }^{131}$

These organisations are defined as 'Queensland Biotechnology Organisations'. ${ }^{132}$ All other organisations undertaking biotechnological activities without Queensland Government involvement can voluntarily subscribe to the Code. In

127 Ibid.

128 Australian Government, National Parks (1 June 2015)<http://www.australia.gov.au/about-australia/ australian-story/national-parks>.

129 In the Northern Territory, the access regime covers all types of landholdings from freehold to leasehold, native title and park land: Biological Resources Act 2006 (NT) s 6.

130 This is also the case in the Northern Territory: see Biological Resources Act 2006 (NT) s 29.

131 Queensland Biotechnology Code of Ethics (updated 2006) 2.

132 Ibid. 
relation to those organisations for which the Code applies, art 10 provides the necessary arrangements where access to Queensland's biological resources are concerned. It is here that access from private land, and land subject to native title rights, is considered. The prior informed consent of the landowner is to be obtained before samples are collected from such privately owned land. Further, a reasonable benefit-sharing arrangement is to be negotiated with that landowner in return for access to those samples. Similarly, compliance with the Native Title Act 1993 (Cth) is required where samples are to be collected from areas subject to native title rights and interests. As for traditional knowledge obtained and used in the course of biodiscovery and research, reasonable benefit-sharing arrangements are to be negotiated with those Indigenous persons and communities providing such knowledge. While this goes some way to addressing the gap in the Biodiscovery Act 2004 (Qld), it does not provide a mechanism for review of such arrangements, nor does it provide any way of determining what is 'prior informed consent' and what constitutes a 'reasonable benefit sharing arrangement'.

\section{THE CASE FOR SUI GENERIS LEGISLATION IN AUSTRALIA}

The way in which a state treats Indigenous or traditional knowledge will have obvious implications for the way it is protected. If Indigenous knowledge is considered by an Indigenous community as their common heritage, then conflict may arise if the information is commodified by intellectual property laws. ${ }^{133}$ Commentators such as Vandana Shiva have mapped several instances of such 'biopiracy' in India. ${ }^{134}$ Conversely, the concept of common heritage has been expanded to encompass the common heritage of the whole of humanity thereby justifying those who would use the knowledge without providing due recognition (let alone compensation) to those who are the traditional holders of that knowledge. ${ }^{135}$ Janke points out that:

A major concern of Indigenous people is that their cultural knowledge of plants, animals and the environment is being used by scientists, medical researchers, nutritionists and pharmaceutical companies for commercial gain, often without their informed consent and without any benefits flowing back to them. ${ }^{136}$

The commercialisation of Indigenous knowledge often occurs through the process of gaining intellectual property protection for inventions derived

133 Gathegi, above n 61, 185.

134 Vandana Shiva, Protect or Plunder? Understanding Intellectual Property Rights (Zed Books, 2001) 49-61.

135 Christopher Arup, 'How Are the Different Views of Traditional Knowledge Linked by International Law and Global Governance?' in Christoph Antons (ed), Traditional Knowledge, Traditional Cultural Expressions and Intellectual Property Law in the Asia-Pacific Region (Kluwer Law International, 2009) $67,69$.

136 Terri Janke, 'Biodiversity, Patent and Indigenous Peoples' (26 June 2000) [2.1]<http://sedosmission. org/old/eng/JankeTerry.htm>. 
from such knowledge — in the form of patents and plant breeders' rights for example. It is arguable that bioprospectors - and ultimately biotechnological and pharmaceutical companies - would not have discovered the correct leads for patentable bioactive materials without the use of such knowledge from local communities in many instances. In its 2005 report on biodiscovery, the Australian Prime Minister's Science Engineering and Innovation Council gave explicit recognition to the role of Indigenous knowledge — and the more broadly defined traditional knowledge. ${ }^{137}$ This knowledge, pertaining to the medicinal and other properties of living organisms, is recognised as an important source of wisdom, providing a catalyst for the biodiscovery ${ }^{138}$ process. ${ }^{139}$ This raises issues of how such knowledge is to be utilised in the biodiscovery process, and what mechanisms should be in place to ensure the benefit flows back to relevant Indigenous communities. The elements of prior informed consent and mutually agreed terms have already been discussed above.

Another significant issue which requires attention is the intergenerational loss of knowledge. This is not a new issue but rather a well-recognised issue that is cause for concern for the knowledge-holders and their communities (and arguably, humanity as a whole). The impact of modern Western knowledge on the loss of traditional ecological knowledge has been traced in the writings of scholars such as Chambers, ${ }^{140}$ Shiva, ${ }^{141}$ and Gupta, ${ }^{142}$ and quantified by scholars such as Haruyama. ${ }^{143}$ Importantly, the holders of cultural knowledge themselves are concerned about the very same issues, as younger generations are increasingly being educated away from country — and therefore spending less time on country, and losing traditional languages and customs through which the cultural knowledge is maintained (often through oral traditions). ${ }^{144}$ Accordingly, there is a strong interest in documenting, recording and recovering knowledge to make it available for future generations of community members. India has achieved this through its Anthropological Survey of India and its Traditional Knowledge Digital Library, which focuses on public domain knowledge in order to prevent

137 Prime Minister's Science Engineering and Innovation Council (PMEIC), 'Biodiscovery' (2 December 2005) 14 ('Biodiscovery Report').

138 'Biodiscovery' was defined as '[t]he extraction and testing of molecules for biological activity, identification of compounds with promise for further development, and research on the molecular basis for the biological activity': House of Representatives Standing Committee on Primary Industries and Regional Services, Parliament of Australia, Bioprospecting: Discoveries Changing the Future: Inquiry into Development of High Technology Industries in Regional Australia Based on Bioprospecting (2001) xxi.

139 Biodiscovery Report, above n 137, 4, 7.

140 Robert Chambers, Rural Development: Putting the Last First (Longman, 1983).

141 Vandana Shiva, Monocultures of the Mind: Perspectives on Biodiversity and Biotechnology (Zed Books, 1993).

142 Anil Gupta, 'The Honey Bee Network: Voices from Grassroots Innovators' (1996) 20 Cultural Survival Quarterly 57.

143 Takako Haruyama, 'Nature of Traditional Ecological Knowledge Loss: A Quantitative Approach' (2004) 11-2 Policy Science $147<$ http://www.ps.ritsumei.ac.jp/assoc/policy_science/112/112_13 haruyama.pdf $>$.

144 Digital Learning Futures, Listening to Wujal Wujal TOs (2010) <http://www.learningfutures.com.au/ listening-wujal-wujal-tos>. 
inappropriate patents from being granted over such knowledge. ${ }^{145}$ A holistic approach is essential to ensure that the integrity of the knowledge is maintained, and is in keeping with ethical research practices. AIATSIS provides such a framework through its Guidelines for Ethical Research in Australian Indigenous Studies which are founded on respect for Indigenous peoples' 'inherent right to self-determination ... and to control and maintain their culture and heritage'. ${ }^{146}$ Various communities are also taking matters into their own hands and documenting their knowledge and culture through a variety of mechanisms, including digital libraries. ${ }^{147}$ It needs to be recognised that these processes are costly, and communities require considerable funding and resources to be able to achieve such goals. The authors submit that what will become necessary in the future is the creation of a complete digital library (or linked libraries) for the purpose of supporting protection and access regimes over Indigenous knowledge and cultural property.

The use of contract law, ${ }^{148}$ and complying with voluntary protocols to protect Indigenous knowledge and culture would seem inadequate as a strategy. Not all Indigenous communities have the same success as the two examples given above. In fact, representatives from the Jarlmadangah Burru community addressed the 2012 Indigenous Knowledge Forum held in Sydney, reporting that despite having been successful with the partnership with Griffith University and having obtained patents, the issue of commercialising this knowledge is the next major hurdle to overcome. ${ }^{149}$ Although it should be noted that at least there is an equal partnership established between the parties for that purpose, and this reinforces the importance of the elements of prior informed consent and adequate benefitsharing arrangements. However, it is arguable that the resultant partnership was due to good legal representation and negotiation rather than any regulatory regime currently in operation in Australia. It should also be noted that the benefit-sharing regimes in Australia over Indigenous knowledge are inconsistent — from binding

145 Traditional Knowledge Digital Library, About TKDL <http://www.tkdl.res.in/tkdl/langdefault/ common/Abouttkdl.asp?GL=Eng>. For further discussion on developments in India see Kanchi Kohli, 'From Congruity to Contract: The Regulatory Design for Knowledge Protection under India's Biodiversity Law' [2013] 94 Intellectual Property Forum 54; Shalini Bhutani, 'In the Knowledge Bazaar - Protecting India's (Biodiversity) Know-How? A Critical Look at Laws and Policies on Traditional Knowledge and Intellectual Property' [2013] 95 Intellectual Property Forum 57; Rajul G Joshi and John Chelliah, 'Sharing the Benefits of Commercialisation of Traditional Knowledge: What Are the Key Success Factors?' [2013] 93 Intellectual Property Forum 60.

146 AIATSIS, 'Guidelines for Ethical Research in Australian Indigenous Studies' (revised 2 $2^{\text {nd }}$ ed, 2012) 3.

147 For example the Jarlmadangah Burru Cultural Mapping Program: <http://web.archive.org/ web/20120317230122/http://www.jarlmadangah.com/culturalmapping.html>; and the Ara Irititja Project which has established a purpose-built database for the Anangu people and is also assisting other Aboriginal communities to do the same: <http://www.irititja.com/sharing_knowledge/index. html>.

148 Such as the benefit-sharing agreements espoused under the $C B D$ art 19 and required in the case of commercial access to Australia's genetic resources under s 301 of the EPBC Act.

149 Paul Marshall and Anthony Watson, 'Partnership Engagement towards the Commercialisation of Indigenous Traditional Knowledge' (Speech delivered at the Indigenous Knowledge Forum, Sydney, 2 August 2012) <http://www.indigenousknowledgeforum.org/index.php/forums/2012-forum/ presentations>. 
obligations found in Commonwealth ${ }^{150}$ and Northern Territory legislation, ${ }^{151}$ to the Code of Ethics in Queensland. This inconsistent approach would arguably encourage forum shopping to take place to benefit bioprospectors.

The importance of establishing sui generis legislation - that has as its primary goal the protection of Indigenous knowledge and culture - is highlighted once again when the secondary nature of the way in which Indigenous knowledge is protected through biodiversity legislation is considered. ${ }^{152}$ This is reinforced by Australia's international obligations discussed above, and has been the focus of the Intergovernmental Committee on Intellectual Property and Genetic Resources, Traditional Knowledge and Folklore in WIPO. While it is more than 20 years since the coming into force of the $C B D$ and 15 years from the time the WIPO took on the task of investigating how traditional knowledge could be protected, there is now a critical mass of international instruments pointing in the same direction towards a sui generis regime (or regimes) that builds on past model laws and regional pacts.

The Intergovernmental Committee of the WIPO has already identified the key elements of an appropriate sui generis regime: the need to satisfy the meaning of traditional knowledge and its scope; the identification of the beneficiaries; the scope of protection encompassing elements of confidentiality and moral rights in the protection against misappropriation and misuse; the nature of the sanctions and remedies (not too dissimilar to those used in intellectual property law); the need for disclosure in the patent and plant variety rights regimes; the establishment of an administrative body or competent authority to manage the data, the rights conferred, and the enforcement; dispute resolution and national treatment; the creation of knowledge databases; and accommodating trans-boundary cooperations where knowledge and biodiversity extend across artificial borders. ${ }^{153}$ These core features identified by WIPO's Intergovernmental Committee must form the basis of Australia's sui generis legislation.

The key elements outlined above are reinforced by the provisions of the Model Law found in the Pacific Regional Framework for the Protection of Traditional Knowledge and Expressions of Culture discussed in Part III above. However, as discussed, the Model Law is more prescriptive, requiring an application process for the use of traditional cultural rights, and the execution of an authorised user agreement. Enforcement employs both criminal and civil sanctions, but equally provides for defences and dispute resolution. The Cultural Authority established or designated to administer the Model Law also has the responsibility to maintain a record of traditional owners and/or knowledge and expressions of culture. While there are many examples of Indigenous communities starting

150 EPBC Regulations reg 8A.07.

151 Biological Resources Act 2006 (NT) pt 4.

152 For arguments in favour of sui generis legislation see Gary D Meyers and Olasupo A Owoeye, 'Intellectual Property Law and the Protection of Indigenous Australian Traditional Knowledge in Natural Resources' (2013) 22(2) Journal of Law, Information and Science 56.

153 WIPO Intergovernmental Committee, The Protection of Traditional Knowledge: Draft Articles, $21^{\text {st }}$ sess WIPO/GRTKF/IC/21/4 (18 January 2012) < http://www.wipo.int/meetings/en/doc_details. jsp?doc_id=195878>. 
their own databases to stave off intergenerational loss of knowledge and culture, such recordings are limited due to lack of funds. Further, these databases have varying levels of quality and comprehensiveness - again, largely due to different levels of funding. A competent authority could provide a degree of co-ordination throughout Australia. To achieve the Indian feat of the Traditional Knowledge Digital Library would require many years and significant resources, but that should not be a deterrent to embarking upon such a venture - particularly for a wealthy nation such as Australia. The authors submit that as part of the process of implementing a sui generis scheme, Australia should now be taking steps towards the establishment of digital database which appropriately captures the Indigenous knowledge of Aboriginal and Torres Strait Islander peoples by assisting communities with collecting and gathering data. While it is beyond the scope of this paper to discuss the key features of this proposed digital database, the Indian Traditional Knowledge Digital Library provides an excellent prototype of what should be included, how it could be coded and how it can be achieved. ${ }^{154}$ Further, the regime proposed in the UTS Submission to IP Australia's public consultation divides such a database into several registers to be administered by a competent authority: a confidential register of 'knowledge holders', ${ }^{155}$ a public register of 'knowledge resources' and a confidential register of 'knowledge resources'. ${ }^{156}$ An additional feature is recognition that two registrars are required, one female and one male, to attend to women's business and men's business respectively, demonstrating the need to be sensitive to the customary law of Aboriginal and Torres Strait Islander communities. ${ }^{157}$ The authors submit that a digital database with these features would make an appropriate fit for an Australian sui generis regime.

The WIPO Intergovernmental Committee was formed with the task of developing model laws under three separate heads: Traditional Knowledge, Genetic Resources, and Traditional Cultural Expressions/Folklore. Adjei and Stoianoff point out that each subject matter 'cut[s] across conventional branches of intellectual property law and do[es] not fit into existing WIPO bodies', ${ }^{158}$ hence the need for the new governance division - the Secretariat for the Intergovernmental Committee.

154 See above $\mathrm{n} 145$ and accompanying text.

155 See UTS Submission, above n 1, 61, 75. 'Knowledge Holders' is defined in the UTS Submission to mean 'members of Aboriginal Communities entrusted with responsibility for Knowledge Resources of the Community': at 61.

156 Ibid 61-2, 75. 'Knowledge Resource(s)' is defined in the UTS Submission to mean 'bodies of knowledge held by Aboriginal Communities relating to the use, care and understanding of Country and the resources found on Country. Knowledge Resources include cultural heritage, traditional knowledge and traditional Cultural Expressions, as well as manifestations of Aboriginal sciences, technologies and cultures, including human and genetic resources, seeds, medicines, knowledge of the properties of fauna and flora, oral traditions, literature, designs, sports and traditional games and visual and performing arts. Knowledge resources include "law knowledge" and "cultural knowledge" of an Aboriginal Community and knowledge of observing ecological interactions between plants, animals, medicines, foods and seasonal cycles which relate to genetic resources. Genetic resources may exhibit different properties in different locations and environments': at 61-2. For a full listing of defined terms, see 60-3.

157 Ibid 76.

158 Adjei and Stoianoff, above n 5, 38. 
One of the main functions of the Secretariat is to prepare and coordinate the meetings of the Committee.

International instruments for the protection of Indigenous knowledge and culture have been the subject of extensive negotiations by WIPO member states under the auspices of the Intergovernmental Committee for well over a decade. Three separate instruments have been developed with varying degrees of overlap. The stream on 'traditional cultural expressions' or 'tradition based creations' has been described as having 'taken a new economic and cultural significance within a globalized information society'. ${ }^{159}$ The subject matter, such as stories, symbols, handicraft and dance, accords closely with copyright, designs and trade mark systems.

Meanwhile, the 'traditional knowledge' stream covers subject matter such as traditional medicinal practices, plant uses, and land management. As Adjei and Stoianoff point out, it 'includes ... genetic resources and views such local and Indigenous knowledge through the lens of the patent system' ${ }^{160}$. The creation of two separate model laws for 'traditional cultural expressions' and 'traditional knowledge' fails to 'reflect the interaction and interdependence of these two "aspects" of traditional or Indigenous culture'. ${ }^{161}$ Adjei and Stoianoff point out that the term "cultural expression" is one of many manifestations of the knowledge in Indigenous culture, as well as a means of preserving, transmitting, using and communicating that knowledge'. ${ }^{162}$

It is far from straightforward to differentiate between the three heads of subject matter that WIPO's Intergovernmental Committee has defined, particularly as these three forms are often intertwined, reinforcing the Indigenous argument that Indigenous knowledge is holistic. ${ }^{163}$ Adjei and Stoianoff give the example of an artist using the traditional knowledge passed down to them 'to create a traditional cultural expression that provides ecological and medicinal knowledge for their community'. ${ }^{164}$ However, this delineation of subject matter has been the basis of negotiations for almost 15 years with the preference for such separate instruments being reinforced in the European Union report to the WIPO General Assembly held in Geneva on 1-9 October 2012. ${ }^{165}$ If this process were to be followed in Australia, the result would be at least two legislative regimes - which seems unwarranted. In our opinion, it is sufficient to provide a uniform sui generis regime for both cultural expressions and Indigenous knowledge, particularly if the regime is kept to a principles-based level as described in the examples above.

159 WIPO Intergovernmental Committee, Elements For The New Mandate - Proposal By The European Community And Its Member States, $14^{\text {th }}$ sess, WIPO/GRTKF/IC/14/11 (July 3, 2009) annex.

160 Adjei and Stoianoff, above n 5, 38.

161 Ibid

162 Ibid.

163 Ibid

164 Ibid (citations omitted).

165 WIPO General Assembly, Matters Concerning the Intergovernmental Committee on Intellectual Property and Genetic Resources, Traditional Knowledge and Folklore (IGC), $41^{\text {st }}\left(21^{\text {st }}\right.$ Extraordinary) sess, WO/GA/41/15 (1 August 2012) 5. 
While it is beyond the scope of this paper to discuss in detail what should be included in Australia's sui generis legislation, the authors agree with Terri Janke's recommendations for such a regime in Our Culture Our Future. ${ }^{166}$ In summary, the key features of this Australian sui generis scheme could include the following:

- the introduction of one Act which deals with the full ambit of rights and responsibilities relating to Indigenous knowledge and culture;

- $\quad$ all definitions to be based on broad community consultations at the local level, and recognising international developments (for example, with reference to the work by the WIPO Intergovernmental Committee);

- $\quad$ provisions which recognise and protect certain rights in perpetuity;

- the protection of Indigenous knowledge and culture in accordance with customary law regardless of whether that knowledge is considered novel or original under intellectual property laws;

- provisions which protect Indigenous knowledge and works that are intangible, and that have not been expressed in material form;

- provisions which prohibit the wilful distortion, misrepresentation and destruction of Indigenous cultural material, and provide special protection for sacred and secret materials, including corresponding sanctions for such offences;

- the availability of both monetary and non-monetary benefits to Indigenous communities for use of their cultural material;

- provisions which prohibit the use of secret/sacred Indigenous knowledge other than in a customary context by customary users;

- $\quad$ provisions which prohibit the use of Indigenous knowledge without adequate documentation of the free, prior and informed consent of the Indigenous owners to an arrangement which contains the sharing of ownership, control, use and benefits;

- $\quad$ prior authorisation provisions based on negotiation, and free and informed consent;

- $\quad$ provisions which establish a central coordination body or competent authority for administering the legislation, assisting in negotiations, collecting licence fees and royalties, education and awareness-raising, investigating alleged breaches, and instituting proceedings against offending parties;

- $\quad$ provisions requiring the competent authority to also establish a mechanism for the mediation of disputes such as a tribunal made up of Indigenous custodians, owners and elders, and specialists in Indigenous law, with avenues of appeal available to an appropriate court in Australia;

166 See Our Culture Our Future, above n 34, ch 18. Several of these key recommendations are put forward by Terri Janke again in her recent submission to IP Australia on its public consultation on Indigenous Knowledge: see Janke and Dawson, above n 2, 24-5. 
- $\quad$ provisions which create a register of protocols or codes of conduct developed by Indigenous communities (such as voluntary collecting schemes) to facilitate authorisation and/or fee collection, and to provide a mechanism for compliance;

- $\quad$ provisions which, along with setting out powers to initiate legal proceedings, provide for remedies for contravention of the rights contained within the legislation, such as damages, account of profits, injunction to restrain use and delivery up of infringing material, and other remedies commonly awarded in intellectual property infringement cases;

- $\quad$ provisions which include a suit of offences for more serious breaches, such as criminal sanctions for severe cases of destruction and mutilation of Indigenous sacred and secret material, fines for unauthorised and misleading use of cultural material, and so on;

- confidentiality provisions which set out what can and what cannot be disclosed to the public;

- $\quad$ provisions which clearly set-out the rights of Indigenous people to control and manage their Indigenous knowledge.

Further, the new legislation will need to consider how it will interact with existing intellectual property laws. For example, the legislation could potentially extend existing moral rights provisions in the Copyright Act 1968 (Cth) to provide for a communal moral right of attribution. The fair dealing provisions could potentially be extended to include research and study for traditional and customary use, and fair dealing for judicial proceedings relating to sacred or secret material.

Of course, as already stated above, there must be extensive consultations with Aboriginal and Torres Strait Islander peoples throughout Australia before any such legislation is introduced. Further, for the purposes of drafting the proposed sui generis scheme, various working parties will need to be established comprising of Indigenous custodians, owners and elders, and specialists in Indigenous law, along with intellectual property and other legal experts. The authors submit that these consultations should take place within the spirit and the framework already set up internationally by art 31 of the UNDRIP, and also the Nagoya Protocol, both discussed above. ${ }^{167}$ Indeed, the work carried out in the UTS Submission for the White Paper prepared for the NSW Office of Environment and Heritage — Recognising and Protecting Aboriginal Knowledge Associated with

167 It should be noted that a number of submissions to IP Australia's public consultation on Indigenous knowledge also support the need for a sui generis scheme provided within this international context. For example, see the Arts Law Centre of Australia, Submission to IP Australia, Indigenous Knowledge Consultation, 14 June 2012, $2<\mathrm{http}$ //www.ipaustralia.gov.au/pdfs/Submission_-_Arts_ Law_Centre_of_Australia.rtf $>$; Indigenous Higher Education Advisory Council, Submission to IP Australia, Indigenous Knowledge Consultation, 8 June 2012, $2<\mathrm{http}$ ://www.ipaustralia.gov.au/ pdfs/Submission_-_Indigenous_Higher_Education_Advisory_Council.pdf $>$; Indigenous Advisory Committee, Submission to IP Australia, Indigenous Knowledge Consultation, June 2012, $5<\mathrm{http} / /$ www.ipaustralia.gov.au/pdfs/Submission___Indigenous_Advisory_Committee.rtf/>; Patricia Adjei, Submission to IP Australia, Indigenous Knowledge Consultation < http://www.ipaustralia.gov.au/ pdfs/Submission_-_Patricia_Adjei.rtf $>$. 
Natural Resource Management - is a recent example of such an action-based methodology. ${ }^{168}$

Given the history of colonialism, dispossession, and the past (and continuing) injustice and marginalisation of Aboriginal and Torres Strait Islander people in Australia, the implementation of a sui generis regime is politically and symbolically important - particularly if Australia is to keep up with regional and international developments in this space. Moreover, while the authors acknowledge the pragmatic approach of scholars such as Bowrey towards protecting Indigenous knowledge and culture, ${ }^{169}$ and certainly agree that a sui generis regime can only reinforce (yet again) Indigenous Otherness, ${ }^{170}$ a sui generis regime is important as it would acknowledge the unique position of Aboriginal and Torres Strait Islander groups as Australia's first peoples. In addition, it is through a sui generis regime that the failings of existing intellectual property laws can be addressed. Anderson considers the arguments raised by Dodson and Blakeney regarding the suitability of the Western framework of intellectual property rights as a means of recognition and protection of Indigenous knowledge and culture. ${ }^{171}$ The difficulty lies in how to characterise that recognition and achieve its protection. The knowledge or the cultural product is part of the community heritage (subject to customary laws), and entrenched in communal and individual responsibilities - as opposed to the strictly private property rights that are typically created through Western intellectual property regimes. However, it is arguable that the goals of recognising and protecting Indigenous knowledge and culture are proprietary in nature if it is acknowledged that the right to exclude others is a key criterion of such recognition and protection. This is a hallmark of Western intellectual property laws. The authors submit that through a sui generis regime in Australia, rights may be moulded to deal with these various failings in order to better protect Indigenous knowledge and culture. Indeed, this is what the WIPO Intergovernmental Committee has been negotiating for more than a decade.

To the question of why Australia should treat Indigenous Australians differently (and specially), the LRCWA Report discussed above stated:

There are a number of arguments that support the legitimacy of differential treatment for Australia's Aboriginal and Torres Strait Islander peoples. The imperative of substantive equality ... is a significant reason for differential treatment and one that can stand alone under both international and Australian law. Other compelling reasons are that Aboriginal people,

168 See UTS Submission, above $\mathrm{n} 1$.

169 Bowrey skilfully shows how existing intellectual property laws can be used to protect Indigenous knowledge and culture, although she does agree that 'the push for sui generis rights remains politically important as it keeps in view the limitations of domestic law and conventional IP categories': Bowrey, 'International Trade in Indigenous Cultural Heritage', above n 2, 423. See also Kathy Bowrey, 'Economic Rights, Culture Claims and a Culture of Piracy in the Indigenous Art Market: What Should We Expect from the Western Legal System?' (2009) 13(2) Australian Indigenous Law Review 35 .

170 Roy, above n 47, 321-30.

171 Jane E Anderson, Law, Knowledge, Culture: The Production of Indigenous Knowledge in Intellectual Property Law (Edward Elgar, 2009) 40-3. 
as members of a distinct indigenous culture, have the right to the legal protection necessary to allow their culture to survive and flourish; that the bias and disadvantage experienced by Aboriginal people makes them more unequal than any other social or cultural group in Australia; that Aboriginal Australians do not access mainstream services at the same rate as other Australians therefore requiring targeted service provision; that Aboriginal people are often subject to two laws and may be punished twice for the same offence; and that Aboriginal people suffer such underlying systemic discrimination in the criminal justice system that they have become the most disproportionately imprisoned culture in Australia. Perhaps the most persuasive argument supporting differential treatment of Aboriginal people by recognition of certain customary laws and practices is found in Aboriginal peoples' unique status as the original inhabitants of Australia. ${ }^{172}$

The authors agree with this justification for 'legitimate differential treatment' for Indigenous Australians - for all of the reasons listed above. ${ }^{173}$ The injustice experienced by Indigenous Australians has been recognised by the Australian Parliament in the historic 'Sorry Speech' of the former Australian Prime Minister, the Honourable Kevin Rudd. On 13 February 2008, a motion of Apology to Australia's Indigenous Peoples was moved and received bipartisan support in Parliament with the aim of 'righting past wrongs' suffered by Australia's Indigenous peoples, with special reference to the Stolen Generations and recognition that 'the laws and policies of successive parliaments and governments ... have inflicted profound grief, suffering and loss'. ${ }^{174}$ In keeping with the theory of corrective justice, it is recognised that wrongs have been committed; there is an identifiable group that has been wronged - Australia's Indigenous peoples; the wrongdoers are an identifiable group - namely successive Australian parliaments; the wrongs unjustifiably caused harm to Australia's Indigenous people; and finally, it is acknowledged that such wrongs need righting. ${ }^{175}$ This, Munzer argues, leads to the sixth step, namely 'recognizing [that some form of intellectual property rights in traditional knowledge] ... would be part of an effective and reasonably efficient means of compensating or restoring justice to the indigenous people ... harmed'. ${ }^{176}$ Given that the wrongs endured by Indigenous Australians have led to intergenerational loss of knowledge and culture through displacement from the land of their ancestors and separation from family and community, it would be a positive first step to establish a sui generis regime that would recognise and protect their unique knowledge and culture — and hopefully provide a platform

172 LRCWA Report, above n 3, 10 (citations omitted).

173 For explanation of the concept of 'legitimate differential treatment' see ibid 9-10.

174 Commonwealth, Parliamentary Debates, House of Representatives, 13 February 2008, 167-73 (Kevin Rudd).

175 Stephen R Munzer, 'Corrective Justice and Intellectual Property Rights in Traditional Knowledge' in Annabelle Lever (ed), New Frontiers in the Philosophy of Intellectual Property (Cambridge University Press, 2012) 58, 61-2.

176 Ibid 62. 
to rebuild it. This would also signal a strong move towards genuine reconciliation in contemporary Australia.

\section{CONCLUSION}

In any attempt to review Australia's historical engagement with the issue of protecting Indigenous knowledge and culture, what becomes quickly apparent is the many failed attempts at establishing a suitable regime. In contrast to these ineffective (although, usually, well-meaning) Australian efforts, there have been several significant advances in this field internationally — including various developments and experiments with establishing sui generis regimes.

While critics commonly argue that drafting grand new sui generis regimes is an overly ambitious (and unnecessary) legislative and political project which would take far too long, it is worthwhile to remember that several of Australia's smaller Pacific neighbours have already made progress on this important issue. Further, there now already exist several national and regional regimes around the world which would provide Australia with guidelines for developing its own legislative regime(s). As the work of the WIPO approaches the completion of workable models for the protection of traditional knowledge and cultural expressions, Australia should really be well on the path to formulating its own regime for Australian Aboriginal and Torres Strait Islander communities. While there has been very little said on Indigenous affairs to date by the current conservative coalition government, Indigenous programs have been brought into the portfolio of the Department of the Prime Minister and Cabinet (although there is still a separate federal Indigenous Affairs Minister). ${ }^{177}$ It will certainly be interesting to see how the current government deals with the critical issue of protecting Australian Indigenous knowledge and culture in this 21 st century.

177 For further detail on the coalition government's published policy on Indigenous issues see The Coalition's Policy for Indigenous Affairs (September 2013) <http://www.naccho.org.au/download/ media-press-releases/2013-09\%20Coalition\%20Indigenous\%20policy\%20Federal $\% 20$ election. pdf $>$. 